\title{
57. NEOGENE INTEGRATED MAGNETOBIOSTRATIGRAPHY OF THE CENTRAL KERGUELEN PLATEAU, LEG 1201
}

\author{
D. M. Harwood, ${ }^{2}$ D. B. Lazarus, ${ }^{3}$ A. Abelmann, ${ }^{4}$ M.-P. Aubry,, 56 W. A. Berggren,${ }^{6}$ F. Heider, ${ }^{7}$ H. Inokuchi, ${ }^{8}$ \\ T. Maruyama, ${ }^{9} \mathrm{~K}$. McCartney, ${ }^{10} \mathrm{~W}$. Wei, ${ }^{11}$ and S. W. Wise, Jr. ${ }^{11}$
}

\begin{abstract}
Neogene biostratigraphic and magnetostratigraphic data are compiled from Holes 747A, 748B, and 751 A drilled on the Southern Kerguelen Plateau during Ocean Drilling Program Leg 120. Neogene sections have excellent to good magnetostratigraphic signatures in many intervals. This, in addition to minimal coring gaps and the occurrence of mixed assemblages of both calcareous and siliceous microfossil assemblages, makes these valuable biostratigraphic reference sections for intra- and extraregional correlations. This paper combines the sequence of biostratigraphic events reported from diatom, radiolarian, planktonic foraminifer, calcareous nannofossil, and silicoflagellate studies of Leg 120 sediments. It correlates microfossil datums with the geomagnetic polarity time scale to test existing age estimates and to refine biostratigraphic age controls for the southern high latitudes.

Significant biostratigraphic datums are presented in a series of age-depth plots. Numerous hiatuses are clearly identified through this approach, and the positions of lesser disconformities are suggested. Most Neogene intervals are represented in at least one site, although "regional" unconformities occur in the upper Pliocene, uppermost Miocene/lowermost Pliocene, middle upper Miocene, middle middle Miocene, and at the lower/middle Miocene boundaries. The longest hiatus spanned $6 \mathrm{~m} . \mathrm{y}$., with most other hiatuses representing $1 \mathrm{~m} . \mathrm{y}$. or less. This paper compiles Leg 120 biostratigraphic and magnetostratigraphic data for use in future syntheses of southern high latitude biostratigraphy and presents an age model for Leg 120 Neogene sediments.
\end{abstract}

\section{INTRODUCTION}

Ocean Drilling Program (ODP) Leg 120 drilled 12 holes at 5 sites (747-751) on the Central Kerguelen Plateau (Fig. 1) during March and April 1988 (Schlich, Wise, et al., 1989). All sites presently lie south of the Polar Front within the Antarctic Water Mass. Leg 120 represents the second half of a two-leg latitudinal transect from the Northern Kerguelen Plateau to the Antarctic Margin near Prydz Bay. Leg 119 drilled 22 holes at 11 sites north and south of the Leg 120 sites (Barron, Larsen, et al., 1989; Barron et al., 1991).

The goals of both legs were (1) to study the Late Cretaceous to Holocene oceanographic history of the southeast Indian Ocean, (2) to study the tectonic evolution of the Kerguelen Plateau and the rifting history of formerly contiguous continental and oceanic blocks, and (3) to gather wellpreserved and continuous records of Cenozoic sediments with

\footnotetext{
${ }^{1}$ Wise, S. W., Jr., Schlich, R., et al., 1992. Proc. ODP, Sci. Results, 120: College Station, TX (Ocean Drilling Program).

2 Department of Geology, 214 Bessey Hall, University of NebraskaLincoln, Lincoln, NE 68588-0340, U.S.A.

${ }^{3}$ Geologisches Institut, Eidgenössische Technische Hochschule, Sonneggstrasse 5, CH-8092 Zürich, Switzerland.

4 Alfred Wegener Institute for Polar and Marine Research, Columbusstrasse, D-2850 Bremerhaven, Federal Republic of Germany.

${ }_{5}^{5}$ Département des Sciences de la Terre, Université Claude Bernard, 27-43 Bd. de 11 Novembre, 69622 Villeurbane Cedex, France.

${ }^{6}$ Department of Geology and Geophysics, Woods Hole Oceanographic Institution, Woods Hole, MA 02543, U.S.A.

${ }^{7}$ Institut für Allgemeine und Angewandte Geophysik, Ludwig-MaximiliansUniversitát, Theresienstrasse 41, 8000 München 2, Federal Republic of Germany.

${ }^{8}$ Marine Biological Station, Faculty of Science, Kobe University, Iwaya, Awaji, Tsuha, Awaji Island, Hyogo 656-24, Japan.

9 Department of Earth Sciences, Yamagata University, Faculty of General Education, Yamagata 990, Japan.

${ }^{10}$ University of Maine at Presque Isle, Presque Isle, ME 04769, U.S.A.

II Department of Geology, Florida State University, Tallahassee, FL 32306, U.S.A.
}

the advanced hydraulic piston corer (APC) that would enable the establishment and refinement of an integrated magnetobiostratigraphy for this section of the Southern Ocean. Successful completion of the latter goal is of great importance for the success of the first two goals and for future research efforts in the Southern Ocean and Antarctic region. This synthesis paper, and papers in this volume from which data were drawn, builds on recent advancements in Neogene integrated magnetobiostratigraphy from ODP Legs 113 and 119 (Gersonde et al., 1990; Barron et al., 1991). At the time of this study, not much information was available from ODP Leg 114.

All sediments discussed herein are pelagic siliceous or calcareous oozes. Drilling in fairly shallow water (all sites were shallower than $1700 \mathrm{~m}$ ) enabled the recovery of a consistent calcareous microfossil component at latitudes where siliceous microfossils are usually the only groups present. This association provided a means of integrating calcareous and siliceous microfossil biostratigraphies and made it possible to correlate high- and low-latitude biostratigraphic zonal schemes. Thus, paleoenvironmental events at the high southern latitudes can be linked to events or responses in the low latitudes. This improved correlation potential is a critical step toward discussions of global system interaction through geologic time.

In general, Pliocene and Pleistocene sediments are diatom ooze or foraminifer diatom ooze, and middle Eocene to upper Miocene sediments are nannofossil ooze or chalk. The exception to this is Site 751, where siliceous microfossils are well represented throughout the Miocene.

\section{APPROACH}

Leg 120 sequences were dated using a combination of biostratigraphic zones and datum levels from calcareous and siliceous microfossil groups (Fig. 2). Ages were applied to these datum levels through identification of anomaly correlatives in the magnetic polarity stratigraphy of Heider et al. (this volume) and Inokuchi and Heider (this volume). Ages of 


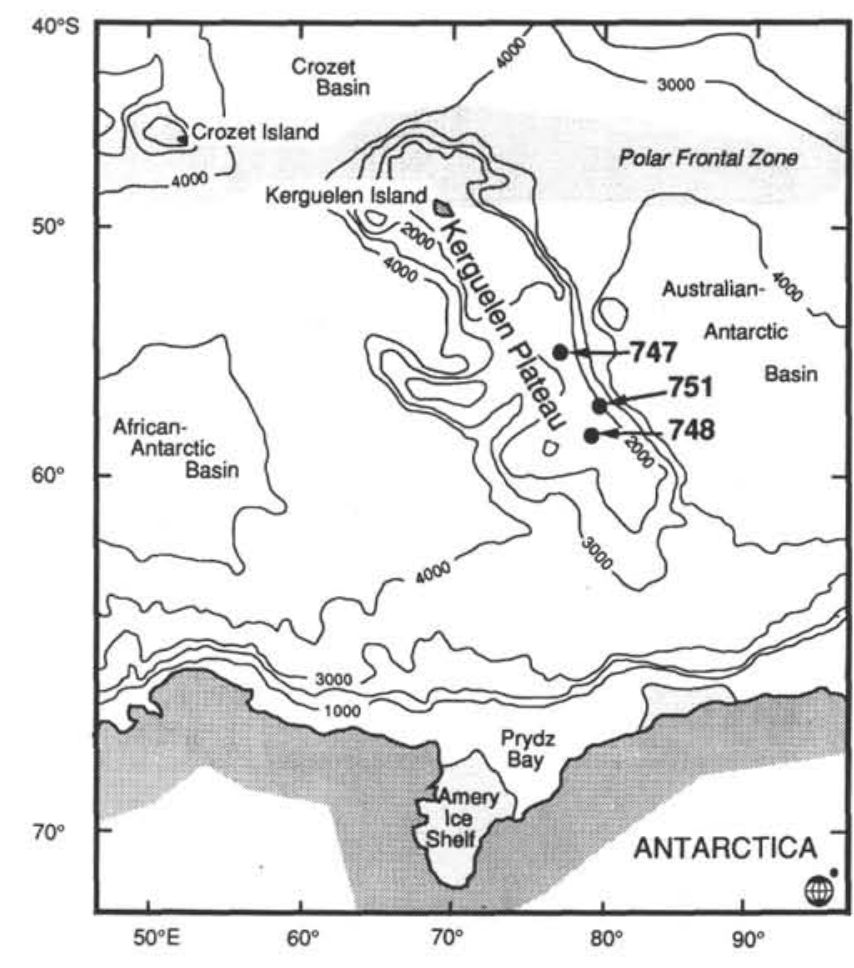

Figure 1. Map of Kerguelen Plateau showing location of Leg 120 sites discussed in this paper (figure from Abelmann, this volume). Bathymetry in meters.

magnetic polarity events follow that of Berggren et al. (1985a, 1985b). Age-depth plots were constructed from the previously published ages of biostratigraphic datums, many of which were only recently calibrated to magnetic events during ODP Legs 113 and 119 (see numerous biostratigraphic papers and syntheses in Barker, Kennett, et al., 1988, 1990; Barron, Larsen, et al., 1989, 1991; and citations in individual chapters in this volume).

Ages given in Schlich, Wise, et al. (1989) were preliminary and are not included among the "published ages" we report herein. The ages assigned to some biostratigraphic datums reflect an average of several ages from the literature because we are not yet in a position to evaluate the validity of one published age over any other. This averaging did not hinder the production of our age-depth plots because it was a collection of all the datums and polarity reversal interpretations that lead to the age-depth correlation line for each Leg 120 site. We then compared the age of the datums at each site with previously published ages.

Ages in the Leg 120 material are clear in many cases. Where several interpretations are possible, these are presented. Some discrepancy will certainly be found between this chapter and other chapters in this volume because of revisions of our age interpretations as this work developed and our data were compiled. It was not possible to revise all of the chapters to reflect the latest thinking. We believe the interpretation presented here to be the best, only because it is the latest to be produced and because we attempt to incorporate all of the available data. We should stress that different methods and tools of age determination have varying degrees of resolution and precision; thus, differences in age models are understandable. We hope the following figures and tables remedy some of the problems that may arise from consulting and comparing results in other papers in this volume.

Biostratigraphic data plotted in the figures largely reflect published ages based on magnetostratigraphic controls (emphasis on ODP Legs 113 and 119 data) or ages deduced from other Leg 120 sites, if no other data were available. References to source publications of the existing age controls, definitions of microfossil zonations, and the techniques we employed are not included here but can be found within individual chapters in this volume and in other biostratigraphic syntheses (e.g., Barron et al., 1991). Ages for each datum and the three-letter code used in the age-depth plots are presented in Table 1 in stratigraphic order for each fossil group. Details regarding Neogene lithostratigraphy, core recovery, and core descriptions can be found in Schlich, Wise, et al. (1989).

A composite sequence of biostratigraphic events at all three sites, as well as existing age estimates, is produced in Table 1 as a test for consistency and to identify existing problem areas and potential diachroneity to be treated in later papers. After the recent advances from biostratigraphic studies on sediments from Legs 113,119, and 120, calibration of the biostratigraphic framework for the Southern Ocean is beginning to stabilize. Little information from Leg 114 is available at the time of this writing. Age resolution and precision made possible by the high-diversity siliceous microfossil assemblages from this region will undoubtedly continue to improve as these materials are compared directly with data from Legs 113, 114, and 119, and as other lesser known microfossil datums are incorporated into this chronologic scheme.

Siliceous microfossil stratigraphy from diatoms (Harwood and Maruyama, this volume) and radiolarians (Abelmann, this volume; Lazarus, this volume) provides the basis for much of the stratigraphic division of Leg 120 Neogene sediments presented here (Fig. 2). Biostratigraphic control for the Neogene from calcareous nannofossils (Schlich, Wise, et al., 1989; Wei and Wise, this volume), foraminifers (Berggren, this volume), and silicoflagellates (McCartney and Harwood, this volume) was limited because of either the rarity of specimens, their low diversity, poor preservation, or the lack of established biostratigraphic controls in this region. Several key datums based on these groups, however, confirm the magnetic polarity interpretations and hiatus position. The utility of the calcareous microfossils increased downcore in the carbonate-rich horizons, but it did not approach the biostratigraphic resolution afforded by the diatoms and radiolarians.

Hiatuses are interpreted largely from the diatom and radiolarian data and by comparing the magnetic stratigraphy (Heider et al., this volume; Inokuchi and Heider, this volume) to the duration of magnetic polarity events in the standard age scale of Berggren et al. (1985a, 1985b). In many cases, the suggested hiatus levels gain support from the coincident position of biostratigraphic zonal boundaries (Fig. 2), polarity event boundaries, and changes in physical properties (Rack and Julson, this volume) and lithology (Schlich, Wise, et al., 1989).

\section{Diatoms}

Marine diatoms are common throughout most of the Neogene. Abundance and state of preservation vary greatly, with the poorest preservation of siliceous microfossils noted in the lower and middle Miocene of Hole 747A. The diatom biostratigraphy applied to Leg 120 sediments is discussed in Harwood and Maruyama (this volume). Information on published diatom ages used in constructing the age-depth plots can be 


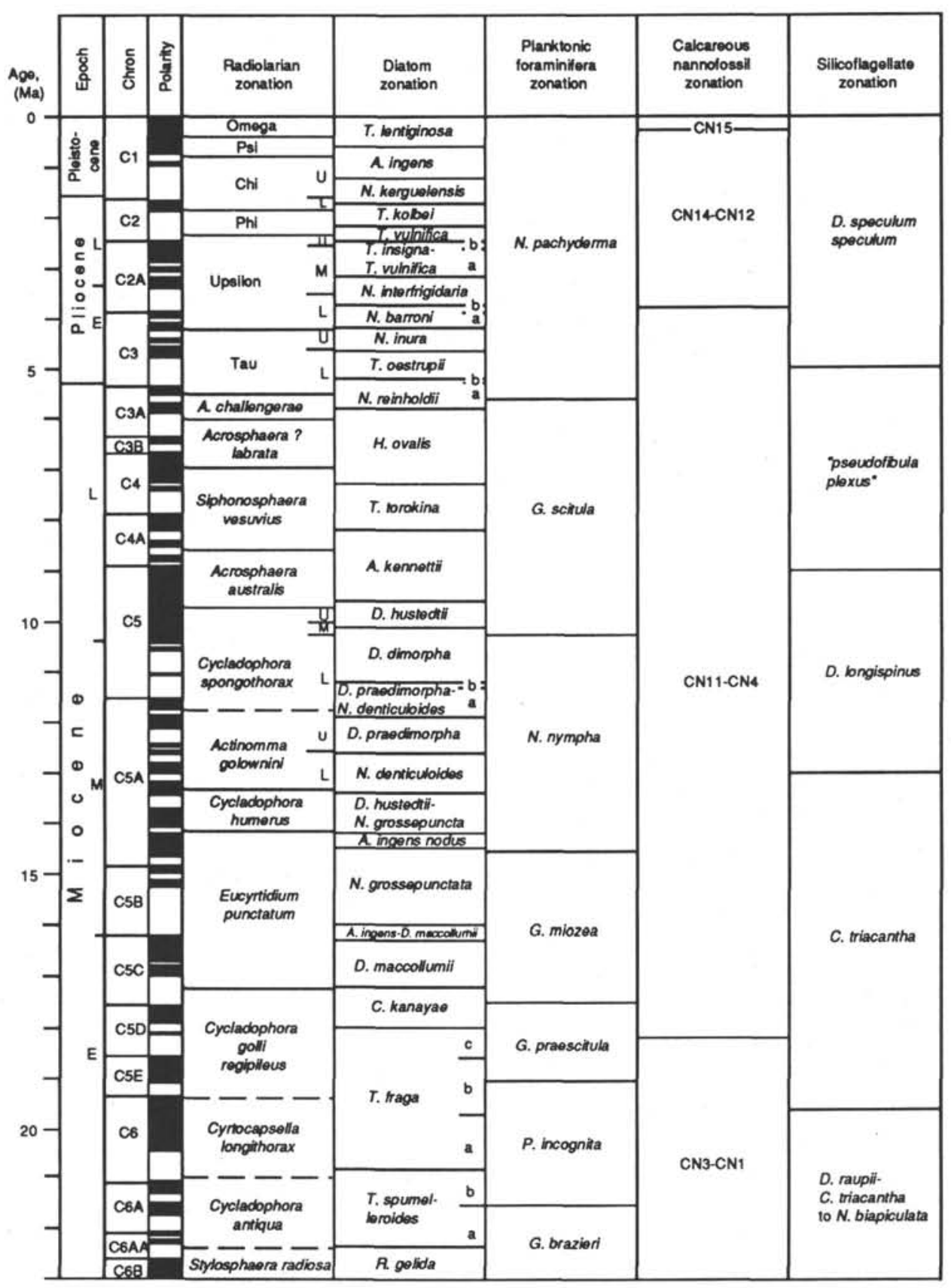

Figure 2. Correlation of biostratigraphic zonations employed in this paper.

found in this work as well as in Baldauf and Barron (1991), Barron et al. (1991), and Gersonde et al. (1990).

\section{Radiolarians}

Neogene radiolarian data for Leg 120 sites were initially generated for the entire Neogene section at each site by Lazarus (Schlich, Wise, et al., 1990, reported in Lazarus, this volume), whereas more detailed data were generated in shorebased studies by Lazarus (this volume) and Abelmann (this volume) for the upper middle Miocene to Holocene and the lower to lower middle Miocene, respectively. Because of publishing constraints, it was not always possible to crosscheck all datum levels before final submission of individual manuscripts. Thus, some discrepancies remain between the radiolarian data and the chosen lines of correlation for each section as well within the radiolarian data itself in the lower part of the Neogene sections. These are discussed below. The reasons for the differences are the rarity of well-preserved specimens in some sections, and the slightly different taxonomic concepts between the two authors.

\section{Foraminifers}

Remarks regarding the biostratigraphic zonations and foraminifer datums used in this paper can be found in the paper by Berggren (this volume) and in Schlich, Wise, et al. (1989, "Explanatory Notes" chapter).

\section{Calcareous Nannofossils}

The abundance of calcareous nannofossils is generally low in the Pliocene-Pleistocene sediments, but consistently high 
Table 1. Biostratigraphic datums and published ages used in producing the age-depth plots.

\begin{tabular}{|c|c|c|c|c|c|c|}
\hline & atum & Definition of datum & $\begin{array}{l}\text { Published } \\
\text { age }(\mathrm{Ma})\end{array}$ & $\begin{array}{c}747 \mathrm{~A} \\
\text { age }\end{array}$ & $\begin{array}{l}748 \mathrm{~B} \\
\text { age }\end{array}$ & $\begin{array}{c}751 \mathrm{~A} \\
\text { age }\end{array}$ \\
\hline \multicolumn{7}{|c|}{ Radiolarians: } \\
\hline TAC & top & A. cylindrica & 0.61 & 0.8 & - & * \\
\hline TPTr & top & P. trilobum & 0.8 & $*$ & - & - \\
\hline TCP & top & C. pliocenica & 1.73 & * & - & - \\
\hline BTA & base & T. antarctica & 1.85 & $*$ & - & $*$ \\
\hline TEC & top & E. calvertense & 1.85 & $*$ & - & - \\
\hline THV & top & H. vema & 2.32 & - & - & - \\
\hline TDS & top & D. spongiosa & 2.34 & - & - & - \\
\hline $\mathrm{BCD}$ & base & C. davisiana & 2.5 & 3.25 & - & - \\
\hline TPT & top & P. titan & 3.32 & $*$ & 3.7 & 3.65 \\
\hline TLC & top & L. coronata & 3.5 & - & $*$ & $*$ \\
\hline BHV & base & H. vema & 4.2 & $*$ & - & * \\
\hline TLG & top common & L. grande & 4.6 & - & - & 5.75 \\
\hline $\mathrm{TACh}$ & top & A. challengerae & 5.5 & $*$ & - & 5.75 \\
\hline $\mathrm{BACh}$ & base & A. challengerae & 6 & 5.6 & - & 5.9 \\
\hline BAL & base & A. labrata & 7 & - & - & - \\
\hline TCS & top & C. spongothrax & 8.3 & 7.8 & $*$ & 8.45 \\
\hline BSP & base common & S. peregrina & 8.4 & $*$ & - & * \\
\hline TLSt & top & L. stigi & 8.49 & * & 8.3 & 8.6 \\
\hline BAA & base & A. australis & 9.7 & $*$ & 9.3 & $*$ \\
\hline BLSt & base & L. stigi & 8.98 & * & 9.3 & 9.6 \\
\hline BEI & base & E. inflatum & 10 & * & $*$ & $*$ \\
\hline TAG & top & A. golownini & 10.2 & * & 10 & * \\
\hline BCS & base & C. spongothrax & 11.8 & 11 & - & * \\
\hline BDM & base & D. megalocephalis & 12.5 & - & - & 13.3 \\
\hline BAD & base & A. deflandrei & 14 & - & - & - \\
\hline $\mathrm{BAG}$ & base & A. golownini & 13.1 & $*$ & - & 13.6 \\
\hline $\mathrm{BCH}$ & base & C. humerus & 14.2 & 14.7 & - & $\cdot$ \\
\hline BEP & base & E. punctatum & 17.3 & 17.6 & - & 17 \\
\hline BCGR & base & C. golli regipileus & 19.4 & - & $>19.7$ & $*$ \\
\hline $\mathrm{BCL}$ & base & C. longithorax & 21 & - & - & - \\
\hline BCT & base & C. tetrapera & 22.5 & 22.1 & - & - \\
\hline \multicolumn{7}{|l|}{ Diatoms: } \\
\hline THK & top & H. karstenii & 0.195 & $*$ & - & - \\
\hline TAI & top & A. ingens & 0.62 & * & * & $*$ \\
\hline TTE & top & A. elliptiporus & 0.65 & 0.8 & * & $*$ \\
\hline TNB & top & N. barronii & 1.25 & * & $*$ & - \\
\hline BTE & base & T. elliptiporus & 1.6 & 1.4 & - & - \\
\hline TTI & top & T. inura & 1.8 & - & - & - \\
\hline TTK & top & T. kolbei & 1.8 & $*$ & - & - \\
\hline TTV & top & T. vulnifica & 2.22 & - & - & - \\
\hline BAA & base & A. actinochilus & 2.3 & - & 3 & - \\
\hline TRD & top & R. diploneides & 2.4 & - & - & - \\
\hline TTI & top & T. insigna & 2.5 & - & - & - \\
\hline TNI & top & N. interfrigidaria & 2.6 & - & - & - \\
\hline TNWe & top & N. weaveri & 2.64 & - & 2.9 & - \\
\hline BNK & base & N. kerguelensis & 2.7 & - & 2.9 & - \\
\hline BTV & base & T. vulnifica & 3.1 & $*$ & $*$ & $*$ \\
\hline TTC & top & T. complicata & 3.1 & 3.3 & 2.9 & * \\
\hline BNWe & base & N. weaveri & 3.2 & 3.3 & - & * \\
\hline TNP & top & N. praeinterfrigidaria & 3.5 & $*$ & 3.3 & * \\
\hline TNWi & top & N. wisei & 3.5 & - & * & $*$ \\
\hline BNI & base & N. interfrigidaria & 3.6 & - & * & 3.7 \\
\hline BTK & base & T. kolbei & 3.8 & - & 3.9 & 3.9 \\
\hline TRHA & top & R. heteropolara var. A & 4 & - & 3.9 & $*$ \\
\hline BTL & base & T. lentiginosa & 3.9 & 4.2 & - & $*$ \\
\hline BNWi & base & N. wisei & 4 & - & 3.8 & 4.1 \\
\hline BRD & base & R. diploneides & 4.1 & - & 3.6 & 4 \\
\hline BNB & base & N. barronii & 4.1 & 4.2 & - & 3.9 \\
\hline BTC & base & T. complicata & 4.3 & - & - & 4.4 \\
\hline BRH & base & R. heteropolara & 4.3 & $*$ & 3.9 & 4.4 \\
\hline BNP & base & N. praeinterfrigidaria & 4.5 & - & - & - \\
\hline
\end{tabular}

throughout the Miocene sections. Preservation of nannofossils is generally moderate, with apparent overgrowth in most of the assemblages. Nannofossil diversity in the sequences studied is low compared with lower latitudes. The calcareous nannofossil biostratigraphy, as applied to Leg 120 sediments, is presented in Wei and Wise (this volume).

For reference to lower latitude stratigraphies, combined Neogene zones are tentatively indicated according to the zonation of Okada and Bukry (1980). Except for Emiliania
Table 1 (continued).

\begin{tabular}{|c|c|c|c|c|c|c|}
\hline & atum & Definition of datum & $\begin{array}{l}\text { Published } \\
\text { age (Ma) }\end{array}$ & $\begin{array}{c}747 \mathrm{~A} \\
\text { age }\end{array}$ & $\begin{array}{l}748 \mathrm{~B} \\
\text { age }\end{array}$ & $\begin{array}{l}751 \mathrm{~A} \\
\text { age }\end{array}$ \\
\hline BTI & base & T. inura & 4.8 & - & - & - \\
\hline BTO & base & $T$. oestrupii & 5.1 & - & - & - \\
\hline TAK & top & A. kennettii & 5.6 & * & - & - \\
\hline BHT & base & H. triangulus & 5.6 & 5.7 & - & - \\
\hline TNM & top & N. mirabilis & 5.8 & 5.3 & - & * \\
\hline BHO & base & H. ovalis & 7.9 & * & - & \\
\hline TDD & top & D. dimorpha & 8 & - & - & \\
\hline BTT & base & T. torokina & 8.2 & 8.5 & * & \\
\hline BAK & base & A. kennettii & 9.6 & - & - & 9.7 \\
\hline TCDDi & top common & D. dimorpha & 10.1 & - & * & $*$ \\
\hline TDP & top & D. praedimorpha & 11.1 & 10.9 & 11.3 & 11.1 \\
\hline TND & top & $N$. denticuloides & 11.3 & 11.1 & * & 11.1 \\
\hline BDDi & base & D. dimorpha & 12.2 & 11.9 & - & 11.9 \\
\hline BDP & base & D. praedimorpha & 12.6 & - & - & 12.8 \\
\hline TNG & top & N. grossepunctata & 12 & 13.2 & - & $*$ \\
\hline TAIn & top & A. ingens nodus & 12.3 & - & - & 11.9 \\
\hline BND & base & $N$. denticuloides & 13.5 & 13.6 & - & 13.6 \\
\hline BCDH & base common & D. hustedtii & 14 & 13.5 & - & - \\
\hline BDH & base & D. hustedtii & 14.2 & * & - & 14.1 \\
\hline TDM & top & D. maccollumii & 14.4 & 14.6 & - & 14 \\
\hline BAIn & base & A. ingens nodus & 14.5 & 14.6 & - & 14.3 \\
\hline BNG & base & N. grossepunctata & 15.5 & * & - & 15.3 \\
\hline BDL & base & D. lauta & 16 & - & - & 15.7 \\
\hline BAI & base & A. ingens & 16.4 & - & - & 15.7 \\
\hline BN17 & base & N. sp. 17 (Schrader) & 16.7. & 17.8 & - & \\
\hline BDM & base & D. maccollumii & 17 & * & - & 16.9 \\
\hline BCK & base & C. kanayae & 17.8 & * & - & 18.1 \\
\hline TCR & top & C. rhombicus & 18.1 & - & * & 18.2 \\
\hline TTF & top & T. fraga & 18.6 & - & - & 18.1 \\
\hline TAS & top & A. symmetricus & 18.6 & - & $*$ & - \\
\hline BTF & base & T. fraga & 20.8 & 21.5 & 21.7 & - \\
\hline TTP & top & T. primalabiata & 21.9 & - & - & \\
\hline TRG & top & R. gelida & 22.7 & 22.6 & - & - \\
\hline \multicolumn{7}{|c|}{ Foraminifers: } \\
\hline BNA & base & N. nympha? & 12 & * & - & 13.3 \\
\hline TGZ & top & G. zealandica & 16.8 & 16.3 & - & - \\
\hline BGZ & base & G. zealandica & 17.6 & $>17.7$ & - & 18 \\
\hline BGM & base & G. miozea & 16.8 & - & - & - \\
\hline TCD & top & C. dissimilis & 16.8 & $>17.7$ & 17.6 & 18.8 \\
\hline BGP & base & G. praescitula & 17.7 & - & - & 18.8 \\
\hline BGWC & base & G. woodi connecta & 23.7 & - & - & - \\
\hline TCC & top & C. cubensis & 30 & - & - & - \\
\hline TCG & top & Chiloguembelina & 30 & * & - & - \\
\hline \multicolumn{7}{|c|}{ Calcareous nannofossils: } \\
\hline BEH & base & E. huxieyi & 0.275 & * & - & - \\
\hline TRG & top & R. gelida & 3.8 & 3.2 & * & 5.8 \\
\hline TRH & top & R. hesslandii & 11.1 & * & 11.8 & 11.3 \\
\hline $\mathrm{BCL}$ & base & C. leptoporus & 18.2 & 18 & 18.1 & 18.1 \\
\hline TRB & top & R. bisecta & 24 & * & - & - \\
\hline
\end{tabular}

Notes: Refer to individual biostratigraphic chapters in this volume for a discussion of these ages and reference to their sources. In cases where several ages exist in the literature, some averaging of datum ages was necessary. Three-letter codes identify microfossil datums. The first letter refers to " $\mathrm{B}$ " for base of range and " $\mathrm{T}$ " for top of range; the second letter is the first letter in the genus name; third and fourth letters identify the species. Ages determined from the age-depth plots for Holes 747A (Fig 4), $748 \mathrm{~B}$ (Fig 6), and $751 \mathrm{~A}$ (Fig 8) are indicated in three columns at right. Asterisks (*) indicate general agreement with published ages, whereas numerical ages suggest ages different from published values for that site. Dashes $(-)$ indicate intervals of no data for comparison, usually caused by a hiatus level.

huxleyi, none of the index taxa of Okada and Bukry (1980) are useful for biostratigraphic zonation because of their absence or scarcity at these high latitudes, but a few nontraditional datums are useful for stratigraphic division. These nontraditional diatoms include the last occurrence (LO) of Reticulofenestra hesslandii, and the first occurrence (FO) of Calcidiscus leptoporus/C. macintyrei. These datums have previously been correlated with magnetostratigraphy at Leg 113 sites in the Weddell Sea and Leg 119 sites on the Kerguelen 
Plateau (Wei and Wise, 1990; Wei and Thierstein, 1991), and they provide useful data for constructing the age-depth curves presented herein.

\section{Silicoflagellates}

Silicoflagellates provide only limited biostratigraphic information for the Neogene of Leg 120, as reported in McCartney and Harwood (this volume).

\section{Magnetic Stratigraphy}

Magnetic polarity data for Neogene sediments of Leg 120 are presented in papers by Heider et al. (this volume) for Holes 747 A and 751 A and by Inokuchi et al. (this volume) for Hole 748B. Correlation of magnetic anomaly correlatives to the polarity stratigraphy presented herein is, in many cases, different from the above two papers. Other papers also identify magnetic anomaly correlatives based on an emphasis on one microfossil group (foraminifers in the case of Berggren, this volume, and Wright and Miller, this volume). We present revisions for each site that are different from the ones found in these papers. A polarity stratigraphy for each site is presented at the left side of each age-depth plot, and magnetic anomaly correlatives are identified and labeled for comparison with the standard polarity stratigraphy pattern (Berggren et al., 1985a, 1985b), which is presented along the base of each figure.

\section{DISCUSSION OF AGE MODELS}

The biostratigraphic zonations for different groups employed on Leg 120 sediments are related to each other in Figure 2. Details of these zonations and their definitions are provided in other papers in this volume. Age-depth plots present the biostratigraphic and magnetostratigraphic data used in this interpretation. These plots were produced by a computer program (Macintosh) written by D. B. Lazarus for ODP format data. The biostratigraphic positions of biostratigraphic datums were plotted using previously published age data, and a tentative age-depth correlation was produced. Paleomagnetic anomaly correlatives were then assigned to the reversal stratigraphy from this correlation and a new line drawn from paleomagnetic data. The age-depth plots attempt to accommodate most of the available data into one scheme for reliable interpretation of paleomagnetic history. Age discrepancies among sites and among published ages reflect the remaining problems of correlation and interpretation to be evaluated in the future.

Significant problems still exist with biostratigraphic correlation between diatoms and radiolarians, and also between the two radiolarian reports (Lazarus, this volume; Abelmann, this volume). Tables outlining these differences in radiolarian events and zonal assignment accompany each site description. Abelmann (this volume) draws attention to the problem of the ages assigned to the diatom Thalassiosira fraga and to the radiolarian Cyrtocapsella tetrapera, in which one (or both) of these is diachronous. $T$. fraga may be slightly older than in the lower latitude Pacific Ocean, or C. tetrapera may be slightly younger. Although the scope of this paper is not broad enough to discuss the problems with many age assignments that plot some distance off from the age-depth correlation lines, it is clear that many problems still exist.

Several foraminifer datums in the lower and middle Miocene plot consistently off the age-depth curve, indicating diachronous ranges between the low and high latitudes. Specifically, the FOs of Globorotalia praescitula and Globorotalia zealandica and the LO of Catapsydrax dissimilis occur 0.5-1.0 m.y. earlier in the southern high latitudes than in the lower latitudes, and the FO of Globorotalia miozea appears

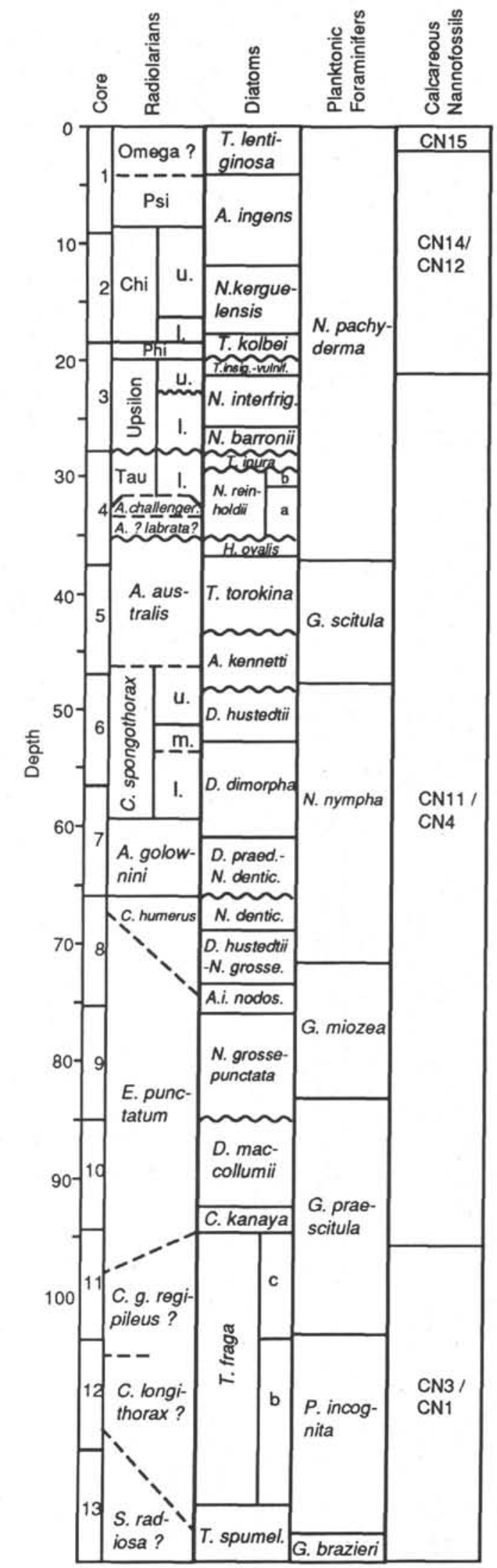

Figure 3. Summary figure showing stratigraphic position of biostratigraphic zones, Hole 747A. In the radiolarian column, diagonal lines show the position of zonal boundaries as given by Lazarus (this volume) at left, and by Abelmann (this volume) at right. The slight differences in position of zonal boundaries between the microfossil groups are in part due to different sample spacing. 

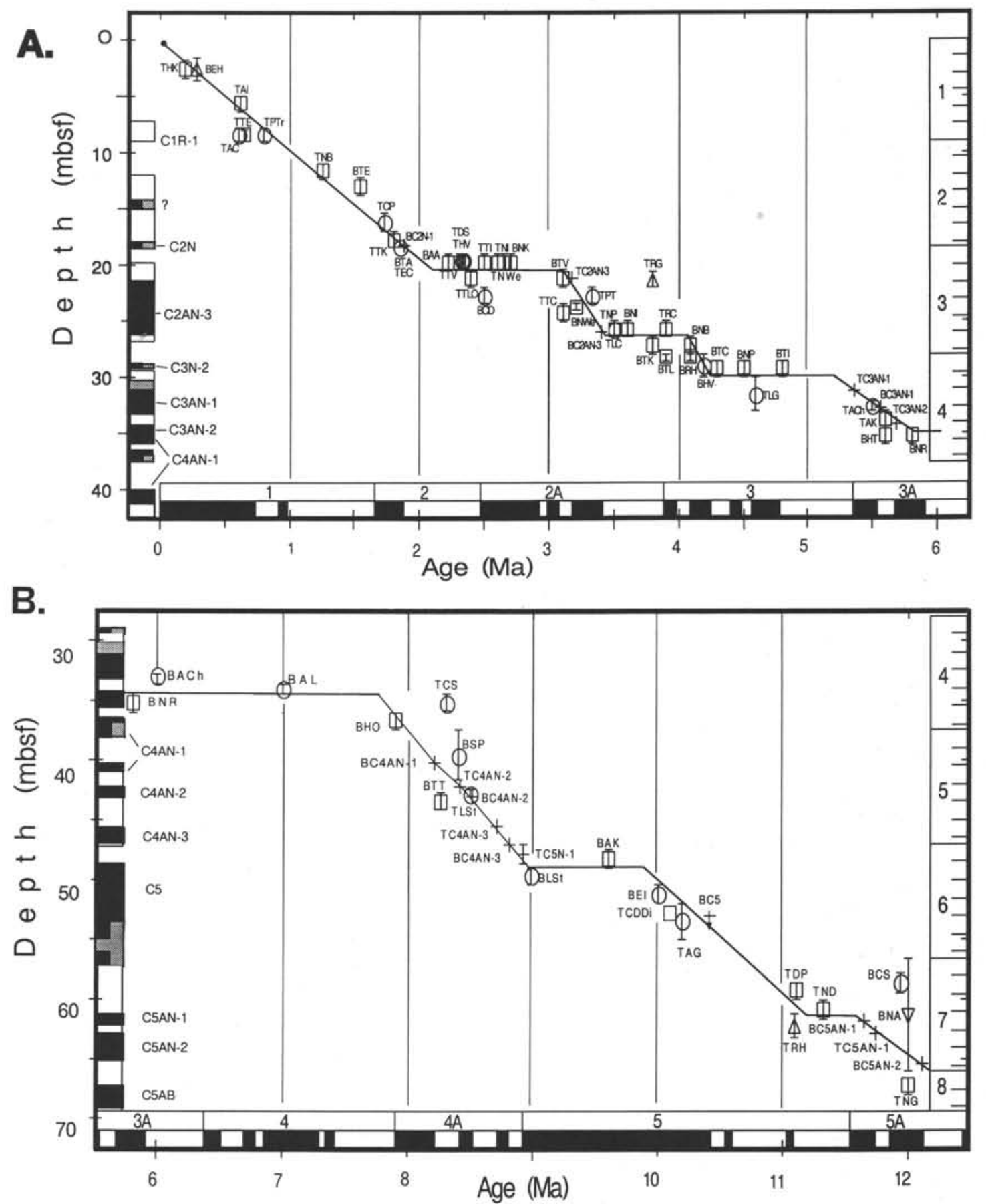

Figure 4. Age-depth plot showing biostratigraphic datums and magnetic stratigraphy for Hole 747A. Three-letter codes refer to microfossil datums listed in Table 1. The first letter refers to B for "base of range" and T for "top of range". The second letter is the first letter in the genus name, followed by one or two letters to identify the species. Open circles $=$ radiolarian datums, open squares $=$ diatom datums, triangle pointing up $=$ foraminifer datums, triangle pointing down $=$ calcareous nannofossil datums, and plus sign $=$ magnetic polarity datums. Magnetic polarity zonation is presented at the left: black $=$ normal polarity, white $=$ reversed polarity, stippled $=$ mixed signal. Half-shaded intervals reflect initially uncertain polarity that was later determined by individual sample measurements. Standard geomagnetic polarity time scale of Berggren et al. (1985) is reproduced at the bottom of the figure with names of the anomaly correlatives. Error bars show depth of uncertainty in datum position caused by sample spacing. Cores are presented at the right side of the figure, with section marks indicated. A. $0-40$ mbsf. B. $30-70$ mbsf. C. $60-100$ mbsf. D. 90-130 mbsf. 

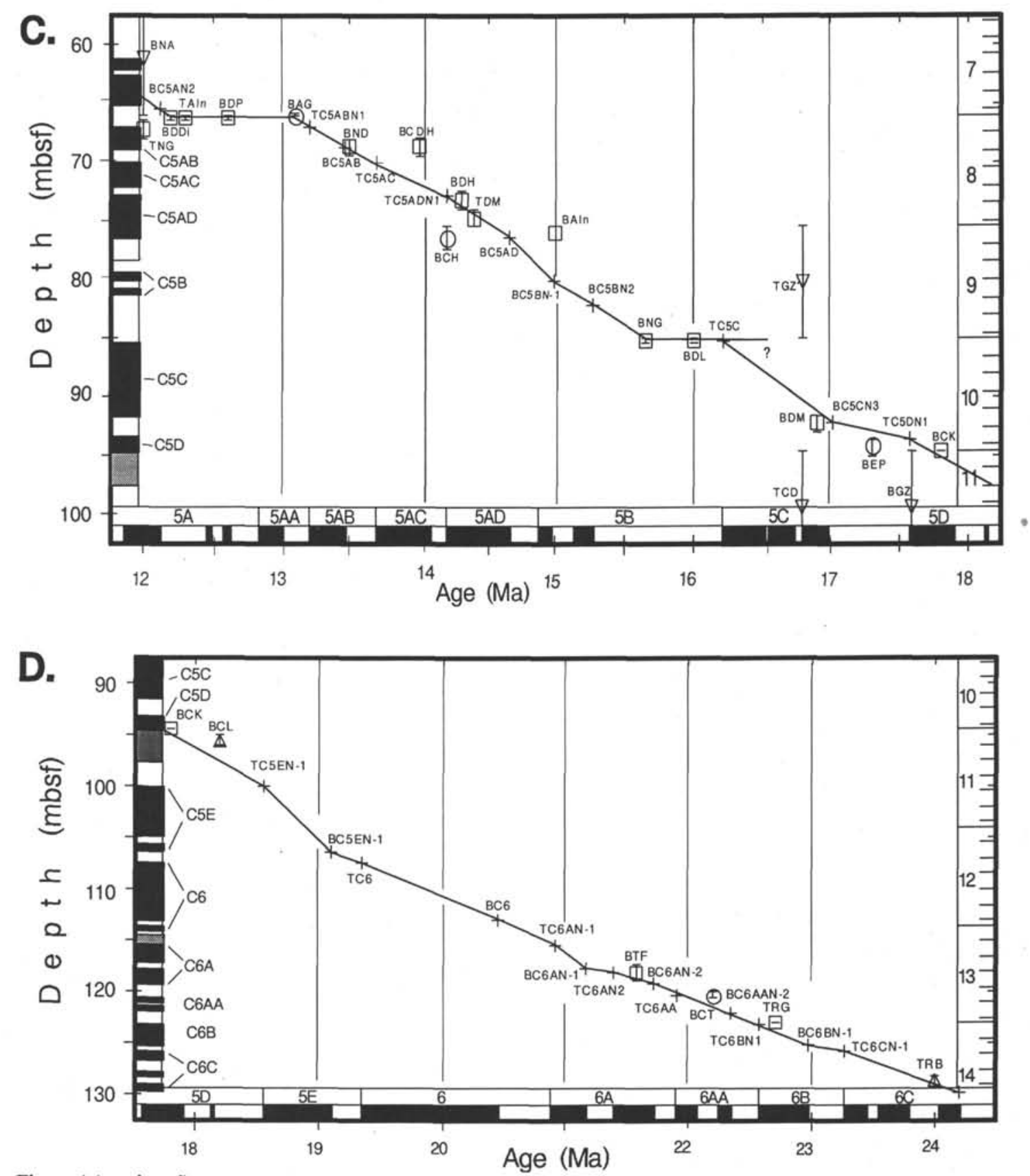

Figure 4 (continued).

1-2 m.y. later than in the lower latitudes. Future discussions of diachronous ranges from Leg 120 data should continue in conjunction with data from Legs 113,114, and 119 to allow for greater temporal and spatial control on the timing of plankton migrations, and for consideration of other paleoceanographic and paleoclimatic factors. The distance of lower and middle Miocene foraminifer datum levels away from the age-depth line could also be explained if previous calibrations of radiolarian and diatom datums for this interval are incorrectly linked to younger ages.

\section{Site 747}

Site 747 was drilled on a broad terrace located in the transition zone between the Northern and Southern Kerguelen plateaus, approximately $500 \mathrm{~km}$ south of the present Polar Front $\left(54^{\circ} 49^{\prime} \mathrm{S}\right.$ and $76^{\circ} 48^{\prime} \mathrm{E}$; water depth, $\left.1697.7 \mathrm{~m}\right)$. A pelagic sedimentary section spanning the lower Santonian through upper Pleistocene (296.5 $\mathrm{m}$ thick) and underlying basalt $(53.9 \mathrm{~m})$ was recovered in the three holes drilled. Objectives of this site were (1) to determine the nature and age of basement at this northern site for comparison with other sites on the Southern Kerguelen Plateau, and (2) to study the paleoceanographic history of the region and trace migrations of the Polar Front through time.

The sedimentary section recovered at Site 747 includes approximately $33 \mathrm{~m}$ of upper Pleistocene to upper Miocene foraminifer diatom ooze (Unit I). Ice-rafted debris and dropstones are prevalent in the upper $20 \mathrm{~m}$ only. Unit I overlies Miocene to lower Paleocene nannofossil ooze and chalk that continues down to 181.45 mbsf. Lower Danian to Santonian sediments (Units II-IV) continue from this level down to 296.5 $\mathrm{m}$ and are underlain by basalt flows to $350.5 \mathrm{mbsf}$. Neogene 
hiatuses occur in the upper Pliocene (2.1-3.1 Ma), the lower Pliocene (3.4-4.1 Ma), across the Pliocene/Miocene boundary (4.3-5.2 Ma), in the upper Miocene (5.8-7.8 and 9.0-9.9 Ma), and in the middle Miocene (11.2-11.6 and 12.2-13 Ma). The middle Miocene to the base of the Miocene is apparently continuous between 13 and $24 \mathrm{Ma}$, except for a minor hiatus from 15.6 to $16.2 \mathrm{Ma}$.

The stratigraphic position of microfossil zonal boundaries in Hole 747A is presented in Figure 3. Four age-depth plots, each representing $6 \mathrm{~m} . \mathrm{y}$. of time, are presented as Figures $4 \mathrm{~A}-4 \mathrm{D}$, with the data used in their construction given in Table 2 . Table 3 presents the magnetic anomaly correlatives identified in this paper and shows the differences between this paper and the identifications made by Heider et al. (this volume). Table 4 presents the different application of radiolarian biostratigraphy between the papers of Lazarus (this volume) and Abelmann (this volume).

Radiolarian and diatom preservation in the lower Neogene in Hole $747 \mathrm{~A}$ is poor to moderate. Only a tentative zonation for this interval was given by Lazarus (this volume), whereas Abelmann (this volume) left this interval unzoned. Given the sporadic nature of their occurrences, the first appearance datums (FADs) of Cyrtocapsella longithorax and Cycladophora golli regipileus are not used in the age-depth figures. The FAD of Cycladophora spongithorax was placed by Lazarus in the upper part of Core 120747 A-7H. Abelmann did not determine the FAD of this taxon because of the poor preservation; instead, she recognizes the FO within the lower part of Core $120-747 \mathrm{~A}-6 \mathrm{H}$ (but does not think that it is a reliable datum because of the poor preservation) and suggests that the FAD may be placed in an older interval that was not recorded because of the poor preservation. This lower level of $C$. spongithorax is closer to the age-depth line of correlation chosen for this site; however, the datum still falls somewhat off the line. The prior age calibration for this datum of $\sim 11.8 \pm 0.5$ Ma (Abelmann, 1990) is based on a low sedimentation rate and possibly stratigraphically incomplete section from Site 689 . In general, Leg 120 results suggest an age near 11.4 Ma.

The FAD of Cycladophora humerus was seen near the top of Core $120-747 \mathrm{~A}-8 \mathrm{H}$ by Lazarus and near the base of the same core by Abelmann. The lower value is closer to the line of correlation. Lazarus placed the FAD of Eucyrtidium punctatum within the lower part of Core $120-747 \mathrm{~A}-11 \mathrm{H}$. Because the preservation of the interval below Core $120-747 \mathrm{~A}-10 \mathrm{H}$ is poor and the stratigraphic marker species are mostly lacking, Abelmann did not determine the FAD of $E$. punctatum but placed the FO of the species at the base of Core 120-747A$10 \mathrm{H}$. For this reason, the FAD of $E$. punctatum may occur in a lower interval that cannot be identified at Site 747. The FAD of Cyrtocapsella tetrapera was placed by Abelmann and Lazarus in the upper part of Core $120-747 \mathrm{~A}-13 \mathrm{H}$.

The FAD of $C$. tetrapera was dated by Berggren et al. (1985a) at around 22.6 Ma (equatorial Pacific). A slightly younger age determination (22.2 Ma) was given for this datum by Barron et al. (1985) based on DSDP Leg 85 investigations. Assuming a synchronous FAD for the cosmopolitan $C$. tetrapera in low latitudes and in the sector of the Southern Ocean investigated here, an age assignment for the base of the Cycladophora antiqua Zone estimated around 22.6 to $22.2 \mathrm{Ma}$ is supported. Takemura (this volume) considered the FAD of C. tetrapera in Sites 748 and 749 to be equivalent to the Miocene/Oligocene boundary (22.3 Ma).

Harwood and Maruyama (this volume) placed the FAD of the diatom species Thalassiosira fraga, which occurs near the base of the $C$. antiqua Zone, in a younger time interval between 21.2 and $20.8 \mathrm{Ma}$. The FAD of $T$. fraga was dated in the low and mid-latitude Pacific between 19.9 and $19.6 \mathrm{Ma}$ (Barron, 1985). Baldauf and Barron (1991) placed the FAD of $T$. fraga between 21 and $20.2 \mathrm{Ma}$, younger than the age determination of Harwood and Maruyama (this volume). Because $C$. tetrapera and $T$. fraga occur in the same core depth, it can be suggested that one species must be diachronous (Abelmann, this volume). However, until now, it was not clear if the base of the $C$. antiqua Zone could be placed at $\sim 22.6-22.2 \mathrm{Ma}$ or to a younger time interval between 20.2 and 21.2 Ma. Similarly, the FAD of $T$. fraga may extend to sediments as old as $21.7 \mathrm{Ma}$ in the Southern Ocean.

\section{Site 748}

Site 748 is located in the western part of the Raggatt Basin on the Southern Kerguelen Plateau $\left(58^{\circ} 27^{\prime} \mathrm{S}\right.$ and $78^{\circ} 59^{\prime} \mathrm{E}$; water depth, $1290 \mathrm{~m}$ ), approximately $900 \mathrm{~km}$ south of the Polar Front. Objectives at this site were to recover an expanded section of Paleogene and Cretaceous sediments and basement to decipher the tectonic, geologic, and paleoceanographic history of the Southern Kerguelen Plateau. Two holes were drilled to a total penetration depth of $935 \mathrm{~m}$. Approximately $15 \mathrm{~m}$ of Pliocene-Pleistocene diatom ooze with radiolarian- and foraminifer-enriched intervals (Unit I) overlie upper Miocene to upper Paleocene nannofossil ooze, chalk, and chert (Unit II) continuing down to 397.4 mbsf. Upper Cretaceous glauconitic sediments (Unit III) continue down to 898.8 mbsf, where basalt was cored to 935 mbsf. The continuous recovery in this interval provided an excellent biosiliceous and calcareous reference section for the southern high latitudes that was calibrated with good paleomagnetic control.

Neogene hiatuses occur in the upper Pleistocene (0-0.7 $\mathrm{Ma})$, the upper Pliocene (1.5-2.9 Ma), the lower Pliocene to middle upper Miocene (4.0-8.0 Ma), the lower upper Miocene (9.3-10 Ma), the middle and upper Miocene (11.9-17.5 Ma), and the lower Miocene (19.9-21.3 and 21.7-22.6 Ma). A thin $(\sim 15 \mathrm{Ma})$ interval of middle Miocene sediment bounded by two long unconformities was noted at $\sim 40$ mbsf. The stratigraphic position of microfossil zonal boundaries in Hole 748B is presented in Figure 5. Three age-depth plots, each representing $8 \mathrm{~m} . \mathrm{y}$. of time, are presented as Figures $6 \mathrm{~A}-6 \mathrm{C}$, with the data used in their construction given in Table 5. Table 6 presents magnetic anomaly correlatives identified in this paper and shows differences between this paper and the identifications of Inokuchi and Heider (this volume). Table 7 presents the different application of radiolarian biostratigraphy between the papers of Lazarus (this volume) and Abelmann (this volume).

\section{Site 751}

Site 751 is located in the central part of the Raggatt Basin on the Southern Kerguelen Plateau $\left(57^{\circ} 44^{\prime} \mathrm{S}\right.$, $79^{\circ} 48^{\prime} \mathrm{E}$; water depth, $1633.8 \mathrm{~m}$ ). The objective of drilling Site 751 was to recover a high-resolution Neogene and Paleogene stratigraphic section that was deposited above the CCD, but south of the Polar Front. A single hole was drilled using the APC, and a 166.2-m section of upper Pleistocene through middle lower Miocene mixed biosiliceous and calcareous ooze was recovered.

Neogene hiatuses occur in Hole 751A in the upper Pleistocene to Holocene $(0-0.6 \mathrm{Ma})$, the lower Pleistocene $(0.7-1.3$ $\mathrm{Ma})$, the upper Pliocene (1.7-3.0 Ma; with a possible period of sedimentation from 2.3-2.5 Ma), the Pliocene/Miocene boundary (4.4-5.7 Ma), the upper Miocene (6.0-8.4 Ma), and the middle Miocene (12.0-12.7 Ma). Furthermore, a probable hiatus was noted in the lower Miocene (15.3-16.0 Ma) at a similar position to the one postulated in Hole 747A. 
Table 2. Biostratigraphic events used to construct agedepth plots, Hole 747A.

\begin{tabular}{|c|c|c|c|c|}
\hline Datum & $\begin{array}{c}\text { Hole } 747 \mathrm{~A} \\
\text { age (Ma) }\end{array}$ & $\begin{array}{l}\text { Published } \\
\text { age (Ma) }\end{array}$ & $\begin{array}{l}\text { Upper } \\
\text { interval } \\
(\mathrm{m})\end{array}$ & $\begin{array}{l}\text { Lower } \\
\text { interval } \\
\text { (m) }\end{array}$ \\
\hline \multicolumn{5}{|c|}{ Radiolarians: } \\
\hline TAC & 0.8 & 0.61 & 7.95 & 9 \\
\hline TPTr & $*$ & 0.8 & 7.95 & 9 \\
\hline TCP & * & 1.73 & 15.45 & 16.95 \\
\hline BTA & * & 1.85 & 18.45 & 18.5 \\
\hline TEC & * & 1.85 & 18.45 & 18.5 \\
\hline THV & - & 2.32 & 18.95 & 20.45 \\
\hline TDS & - & 2.34 & 18.95 & 20.45 \\
\hline BCD & 3.25 & 2.5 & 21.95 & 23.45 \\
\hline TPT & $*$ & 3.32 & 21.95 & 23.45 \\
\hline TLC & - & 3.5 & 24.95 & 26.45 \\
\hline BHV & * & 4.2 & 28 & 29.95 \\
\hline TLG & - & 4.6 & 29.95 & 32.95 \\
\hline TACh & $*$ & 5.5 & 32.1 & 32.95 \\
\hline BACh & 5.6 & 6 & 32.95 & 33.6 \\
\hline BAL & - & 7 & 33.6 & 34.45 \\
\hline TCS & 7.8 & 8.3 & 34.45 & 35.95 \\
\hline BSP & * & 8.4 & 37.5 & 41.62 \\
\hline TLSt & * & 8.49 & 42.45 & 43.12 \\
\hline BLSt & * & 8.98 & 48.95 & 50.45 \\
\hline BEI & * & 10 & 50.45 & 51.95 \\
\hline TAG & * & 10.2 & 51.95 & 54.95 \\
\hline BCS & 11 & 11.8 & 57.7 & 59.5 \\
\hline BAG & $*$ & 13.1 & 65.95 & 66 \\
\hline $\mathrm{BCH}$ & 14.7 & 14.2 & 75.5 & 77.5 \\
\hline BEP & 17.6 & 17.3 & 94.5 & 95 \\
\hline BCT & 22.1 & 22.5 & 118.8 & 120 \\
\hline \multicolumn{5}{|l|}{ Diatoms: } \\
\hline THK & * & 0.195 & 1.97 & 3.47 \\
\hline TAI & $*$ & 0.62 & 4.97 & 6.47 \\
\hline TTE & 0.8 & 0.65 & 7.97 & 9 \\
\hline TNB & $*$ & 1.25 & 10.97 & 12.47 \\
\hline BTE & 1.4 & 1.6 & 12.47 & 13.97 \\
\hline TTK & $*$ & 1.8 & 16.97 & 18.5 \\
\hline TTV & - & 2.22 & 18.97 & 20.47 \\
\hline BAA & - & 2.3 & 18.97 & 20.47 \\
\hline TTLO & - & 2.4 & 20.47 & 21.97 \\
\hline TTI & - & 2.5 & 18.97 & 20.47 \\
\hline TNWe & - & 2.64 & 18.97 & 20.47 \\
\hline TNI & - & 2.6 & 18.97 & 20.47 \\
\hline BNK & - & 2.7 & 18.97 & 20.47 \\
\hline BTV & * & 3.1 & 20.47 & 21.97 \\
\hline TTC & 3.3 & 3.1 & 23.47 & 24.97 \\
\hline BNWe & 3.3 & 3.2 & 23.47 & 24.07 \\
\hline TNP & $*$ & 3.5 & 24.97 & 26.47 \\
\hline BNI & - & 3.6 & 24.97 & 26.47 \\
\hline BTK & - & 3.8 & 26.47 & 28 \\
\hline TRC & - & 4 & 24.97 & 26.47 \\
\hline BRD & - & 4.1 & 26.47 & 28 \\
\hline BTL & 4.2 & 3.9 & 28 & 28.47 \\
\hline BNB & 4.2 & 4.1 & 28 & 28.47 \\
\hline BTC & - & 4.3 & 28.47 & 29.98 \\
\hline BRH & $*$ & 4.3 & 28.47 & 29.98 \\
\hline BNP & - & 4.5 & 28.47 & 29.98 \\
\hline BTI & - & 4.8 & 28.47 & 29.98 \\
\hline TAK & $*$ & 5.6 & 32.98 & 34.48 \\
\hline BHT & 5.7 & 5.6 & 34.48 & 35.98 \\
\hline BNR & - & 5.8 & 34.48 & 35.98 \\
\hline BHO & * & 7.9 & 35.98 & 37.48 \\
\hline BTT & 8.5 & 8.2 & 42.72 & 43.97 \\
\hline BAK & - & 9.6 & 47.47 & 48.97 \\
\hline TCDDi & - & 10.1 & 51.97 & 53.47 \\
\hline TDP & 10.9 & 11.1 & 58.47 & 59.97 \\
\hline TND & 11.1 & 11.3 & 59.97 & 61.47 \\
\hline BDDi & 11.9 & 12.2 & 66 & 66.47 \\
\hline BDP & - & 12.6 & 66 & 66.47 \\
\hline TNG & 13.2 & 12 & 66.47 & 67.97 \\
\hline TAIn & - & 12.3 & 66 & 66.47 \\
\hline BND & 13.6 & 13.5 & 67.97 & 69.47 \\
\hline $\mathrm{BCDH}$ & 13.5 & 14 & 67.97 & 69.47 \\
\hline
\end{tabular}

Table 2 (continued).

\begin{tabular}{|c|c|c|c|c|}
\hline Datum & $\begin{array}{c}\text { Hole } 747 \mathrm{~A} \\
\text { age (Ma) }\end{array}$ & $\begin{array}{l}\text { Published } \\
\text { age (Ma) }\end{array}$ & $\begin{array}{l}\text { Upper } \\
\text { interval } \\
\text { (m) }\end{array}$ & $\begin{array}{l}\text { Lowe } \\
\text { interv: } \\
\text { (m) }\end{array}$ \\
\hline BDH & * & 14.2 & 72.47 & 73.9 \\
\hline TDM & 14.6 & 14.4 & 73.97 & 75.5 \\
\hline BAIn & 14.6 & 15 & 75.5 & 76.6 \\
\hline BNG & $\because$ & 15.5 & 85 & $85.4 ?$ \\
\hline BDL & - & 16 & 85 & 85.4 \\
\hline BDM & * & 17 & 91.47 & 92.9 \\
\hline BCK & - & 17.8 & 94.47 & 94.5 \\
\hline BTF & 21.5 & 20.8 & 116.97 & 118.47 \\
\hline TRG & 22.6 & 22.7 & 123 & 123 \\
\hline \multicolumn{5}{|c|}{ Foraminifers: } \\
\hline BNA & * & 12 & 56.5 & 66 \\
\hline TGZ & 16.3 & 16.8 & 75.5 & 85 \\
\hline BGZ & $>17.7$ & 17.6 & 94.5 & 104 \\
\hline TCD & $>17.7$ & 16.8 & 94.5 & 104 \\
\hline & $*$ & 30 & 151.5 & 161 \\
\hline
\end{tabular}

Calcareous nannofossils:

$\begin{array}{lllrr}\text { BEH } & * & & \\ \text { TRG } & 3.2 & 0.275 & 1.6 & 3.58 \\ \text { TRH } & * & 11.8 & 20.58 & 22.08 \\ \text { BCL } & 18 & 18.2 & 61.15 & 63.08 \\ \text { TRB } & * & 24 & 95.08 & 96.1 \\ & & & 128.08 & 129.1\end{array}$

Magnetic anomaly correlatives: BC2N-1

TC2A

TC2AN-3

$\mathrm{BC} 3 \mathrm{~N}-2$

TC $3 \mathrm{~N}-3$

TC3AN-1

BC3AN-1

TC3AN-2

BC4AN-1

TC4AN-2

TC4AN-3

BC4AN-3

TC5N-1

$\mathrm{BC} 5$

BC5AN-1

TC5AN-2

BC5AN-2

TC5ABN-1

BC5AB

TCSACN1

TC5ADN

BC5AD

BC5BN-1

BC5BN-2

TC5CN-1

BC5CN-3

TC5DN-1

TC5EN-1

BC5EN-1

TC6

BC6

TC6AN-1

BC6AN-1

TC6AN-2

BC6AN-2

TC6AA

BC6AAN-2

TC6BN-1

$\begin{array}{lll}1.88 & 18.4 & 18.4\end{array}$

BC6BN-1

$\begin{array}{lll}3.18 & 21.3 & 21.3\end{array}$

$\begin{array}{lll}4.24 & 29 & 29\end{array}$

$4.4 \quad 31 \quad 31$

$\begin{array}{lll}5.35 & 31.5 & 31.5\end{array}$

$\begin{array}{lll}5.53 & 33 & 33\end{array}$

$\begin{array}{lll}5.68 & 34.5 & 34.5\end{array}$

$8.21 \quad 41.2 \quad 41.2$

$8.41 \quad 42.3 \quad 42.3$

$\begin{array}{lll}8.41 & 42.3 & 42.3 \\ 8.71 & 45.5 & 45.5\end{array}$

$\begin{array}{lll}8.8 & 46.7 & 46.7\end{array}$

$8.92 \quad 47 \quad 48.6$

$\begin{array}{lll}0.42 & 54.9 & 54.9\end{array}$

$\begin{array}{lll}10.42 & 54.9 & 54.9 \\ 11.73 & 62.2 & 62.2\end{array}$

$\begin{array}{lll}1.73 & 62.2 & 62.2 \\ 1.86 & 62.5 & 62.5\end{array}$

$\begin{array}{lll}12.12 & 65.1 & 65.1\end{array}$

$\begin{array}{lll}13.2 & 67.1 & 67.1\end{array}$

$\begin{array}{lll}13.46 & 68.9 & 68.9\end{array}$

$\begin{array}{lll}13.69 & 70.1 & 70.1\end{array}$

$\begin{array}{lll}14.2 & 72.8 & 72.8\end{array}$

$\begin{array}{lll}14.2 & 72.8 & 72.8 \\ 14.66 & 76.5 & 76.5\end{array}$

$\begin{array}{lll}14.96 & 80.75 & 80.75\end{array}$

$15.27 \quad 81.3 \quad 81.3$

$\begin{array}{lll}1.27 & 81.3 & 81.3 \\ 16.22 & 85.5 & 85.5\end{array}$

$\begin{array}{lll}16.22 & 85.5 & 85.5 \\ 16.98 & 91.5 & 91.5\end{array}$

$\begin{array}{lll}6.98 & 91.5 & 91.5 \\ 7.57 & 93.5 & 93.5\end{array}$

$\begin{array}{lll}8.56 & 100 & 100\end{array}$

$\begin{array}{lll}19.09 & 106.4 & 106.4\end{array}$

$\begin{array}{lll}19.35 & 107.5 & 107.5\end{array}$

$\begin{array}{lll}20.45 & 112.9 & 112.9\end{array}$

$\begin{array}{lll}20.88 & 115.4 & 115.4\end{array}$

$\begin{array}{lll}20.88 & 115.4 & 115.4 \\ 21.16 & 116.8 & 116.8\end{array}$

$\begin{array}{lll}21.38 & 117.5 & 117.5\end{array}$

$\begin{array}{lll}21.71 & 119.1 & 119.1\end{array}$

$\begin{array}{lll}21.9 & 120.6 & 120.6\end{array}$

$\begin{array}{lll}22.35 & 121.65 & 121.65\end{array}$

$\begin{array}{lll}22.57 & 123.1 & 123.1\end{array}$

$\begin{array}{llll}\text { TC6CN-1 } & 23.27 & 125.7 & 125.7\end{array}$

$\begin{array}{llll}\text { BC6CN-3 } & 24.21 & 129.65 & 129.65\end{array}$

Notes: Biostratigraphic datums, three-letter codes, and published ages are as in Table 1. Asterisks (*) indicate general agreement with published ages, whereas numerical ages suggest ages different from published values for that site. Dashes (-) indicate intervals of no data for comparison, usually caused by a hiatus level. 
Table 3. Identification of magnetic anomaly correlatives in Hole 747 $\mathrm{A}$ following the age-depth plot in Figure 4.

\begin{tabular}{|c|c|c|}
\hline $\begin{array}{l}\text { Magnetic } \\
\text { event }\end{array}$ & $\begin{array}{l}\text { This } \\
\text { paper }\end{array}$ & $\begin{array}{l}\text { Heider et } \\
\text { al. (this } \\
\text { volume) }\end{array}$ \\
\hline $\mathrm{C} 1$ & $\mathrm{x}$ & $\mathrm{x}$ \\
\hline $\mathrm{C} 2$ & $\mathrm{C} 2$ ? & $\mathrm{x}$ \\
\hline $\mathrm{C} 2 \mathrm{AN}-1$ & $\mathrm{X}$ & $\mathrm{x}$ \\
\hline $\mathrm{C} 2 \mathrm{AN}-2$ & $\mathrm{x}$ & $\mathrm{x}$ \\
\hline $\mathrm{C} 2 \mathrm{AN}-3$ & $\mathrm{C} 2 \mathrm{AN}-3$ & $\mathrm{C} 2 \mathrm{~A}$ \\
\hline $\mathrm{C} 3 \mathrm{~N}-1$ & $\mathrm{x}$ & \# \\
\hline $\mathrm{C} 3 \mathrm{~N}-2$ & $\mathrm{C} 3 \mathrm{~N}-2$ & \# \\
\hline $\mathrm{C} 3 \mathrm{~N}-3$ & $\mathrm{x}$ & \# \\
\hline C3AN-1 & C3AN-1 & C3 \\
\hline C3AN-2 & C3AN-2 & $\mathrm{x}$ \\
\hline $\mathrm{C} 4 \mathrm{~N}-1$ & $\mathrm{X}$ & $\mathrm{x}$ \\
\hline $\mathrm{C} 4 \mathrm{~N}-2$ & $\mathrm{x}$ & $\mathrm{x}$ \\
\hline $\mathrm{C} 4 \mathrm{~N}-3$ & $\mathrm{x}$ & $x$ \\
\hline C4AN-1 & C4AN-1? & $\mathrm{x}$ \\
\hline C 4 AN-2 & C $4 A N-2$ & $\mathrm{C} 4 \mathrm{~A}$ \\
\hline C4AN-3 & C4AN-3 & C4AN-3 \\
\hline $\mathrm{C} 5 \mathrm{~N}-1$ & $\mathrm{C} 5 \mathrm{~N}-1$ & C5 \\
\hline C $5 \mathrm{~N}-2$ & $\mathrm{x}$ & $\mathrm{X}$ \\
\hline $\mathrm{C} 5 \mathrm{~N}-3$ & $\mathrm{x}$ & $\mathrm{x}$ \\
\hline C5AN-1 & C5 $\mathrm{AN}-1$ & C5A \\
\hline C5AN-2 & C5AN-2 & C5AA \\
\hline C5AN-3 & $\mathrm{x}$ & $\mathrm{X}$ \\
\hline C5AN-4 & $\mathrm{x}$ & $\mathrm{x}$ \\
\hline C5AA & $\mathrm{x}$ & $\#$ \\
\hline $\mathrm{C} 5 \mathrm{AB}$ & C5AB & C5 AB \\
\hline $\mathrm{C} 5 \mathrm{AC}$ & C5AC & C 5 AC \\
\hline C5AD & C5AD & C5AD \\
\hline C5BN-1 & C5BN-1 & C5B \\
\hline C5BN-2 & C5BN-2 & C5B \\
\hline $\mathrm{C} 5 \mathrm{CN}-1$ & C5C & C5C \\
\hline $\mathrm{C} 5 \mathrm{CN}-2$ & C5C & $\mathrm{CsC}$ \\
\hline $\mathrm{C} 5 \mathrm{CN}-3$ & C5C & $\mathrm{CsC}$ \\
\hline C5DN-1 & C5D & C5D \\
\hline C5DN-2 & $\mathrm{x}$ & $\mathrm{x}$ \\
\hline C5E & C5E & C5E \\
\hline $\mathrm{C} 6$ & C6 & $\mathrm{C} 6$ \\
\hline C6AN-1 & C6AN-1 & C6A \\
\hline C6AN-2 & C6AN-2 & C6A \\
\hline C6AAN-1 & C6AAN-1 & C6AA \\
\hline C6AAN-2 & C6AAN-2 & C6AA \\
\hline C6B & C6B & C6B \\
\hline $\mathrm{C} 6 \mathrm{CN}-1$ & $\mathrm{C} 6 \mathrm{CN}-1$ & C6C \\
\hline $\mathrm{C} 6 \mathrm{CN}-2$ & $\mathrm{C} 6 \mathrm{CN}-2$ & C6C \\
\hline C6CN-3 & $\mathrm{C} 6 \mathrm{CN}-3$ & C6C \\
\hline
\end{tabular}

Notes: Differences in interpretation between this paper and that of Heider et al. (this volume) are identified. Magnetic polarity events not identified in this hole, usually because of the presence of a hiatus, are identified by the letter X. The "\#" symbol indicates that the magnetic event was identified at a different depth in earlier interpretations.
The stratigraphic positions of microfossil zonal boundaries in Hole 751A are presented in Figure 7. Five age-depth plots, representing from 4 to $6 \mathrm{~m}$.y. of time, are presented in Figures $8 \mathrm{~A}-8 \mathrm{E}$, with the data used in their construction given in Table 8 . Table 9 presents magnetic anomaly correlatives identified in this paper and shows differences between this paper and the identifications of Heider et al. (this volume). Table 10 presents the different application of radiolarian biostratigraphy between the papers of Lazarus (this volume) and Abelmann (this volume). The FAD of the radiolarian Dendrospyris megalocephalis used in the age-depth plots is that given by Abelmann (at the base of Core 120-751A-12H). Rare occurrences of $D$. megalocephalis were observed by Abelmann and common occurrences by Lazarus throughout Core 120-751A-12H. Lazarus found sporadic occurrences of this taxon in Sections $120-751 \mathrm{~A}-16 \mathrm{H}-\mathrm{CC}$ and $-15 \mathrm{H}-\mathrm{CC}$. Taxonomic differences are probably responsible for the different ranges reported.

\section{HIATUSES AND SEDIMENTATION ACCUMULATION RATES}

The distribution of hiatuses in Holes 747A, 748B, and 751A is presented in Figure 9. Possible "regional" hiatuses on the Kerguelen Plateau (identified at all three sites) occur in the upper Pliocene (2.2-3.0 Ma), the Pliocene/Miocene boundary interval (4.4-5.3), the upper Miocene (5.8-8 Ma), the middle Miocene (12.2-12.8 Ma), and possibly the lower/middle Miocene boundary interval (15.6-16.4 Ma). Other upper Neogene unconformities of more local extent are noted in diatom biostratigraphic studies by Jenkins (1987) and Harwood and Maruyama (this volume). These occur in the upper Pleistocene (0.0-0.65 Ma), the upper Pliocene/lower Pleistocene (1.5-2.8 Ma), the middle Pliocene (3.2-3.8 Ma), and the lower Pliocene (4.0-4.2 Ma). Approximate rates of sedimentation can be interpreted from the size of individual cores in Figure 9 , and from the slope of correlation lines in the age-depth curves (Figs. 4, 7, and 10) presented here.

\section{Suggestions for Future Research}

The conclusion of four recent Southern Ocean ODP legs and the publication of the resultant data do not imply that most biostratigraphic problems for this region are resolved. Certainly, many advancements have been made, and the detailed dating provided here would not have been possible without the previous efforts of ODP Leg 113 and 119 scientists; however, much remains to be done. Several outstanding tasks include (1) recovering more materials to fill in the temporal and geographic gaps; (2) obtaining better paleomagnetic records from poorly recorded or disturbed intervals; (3) applying $\mathrm{Sr}$ isotope stratigraphy to existing materials, as was done for Leg 119, where possible; (4)

Table 4. Comparison of Miocene radiolarian events in Hole 747A.

\begin{tabular}{|c|c|c|}
\hline Hole 747A & Lazarus (this volume) & Abelmann (this volume) \\
\hline C. tetrapera & $12 \mathrm{H}-\mathrm{CC}$ is the oldest sample investigated & FAD $13 \mathrm{H}-3,45-47 \mathrm{~cm}$ \\
\hline C. longithorax & Occurrence only in $12 \mathrm{H}-6,45-47 \mathrm{~cm}(? \mathrm{R})$ and $10 \mathrm{H}-\mathrm{CC}$ & Unzoned interval \\
\hline C. golli regipileus & Occurrence in $11 \mathrm{H}-\mathrm{CC}(? \mathrm{R}), 11 \mathrm{H}-2,45-47 \mathrm{~cm}$, and $10 \mathrm{H}-6,45-47 \mathrm{~cm}$ & $\begin{array}{l}\text { Unzoned interval; FAD } C \text {. golli regipileus: } \\
10 \mathrm{H}-6,45-47 \mathrm{~cm}\end{array}$ \\
\hline E. punctatum & $\begin{array}{l}\text { FAD } 11 \mathrm{H}-2,45-47 \mathrm{~cm} \text {; above } 10 \mathrm{H}-4,45-47 \mathrm{~cm} \text {, continuous } \\
\text { occurrence }\end{array}$ & FAD 10H-CC \\
\hline C. humerus & FAD $8 \mathrm{H}-1,45-47 \mathrm{~cm}$ & $\begin{array}{l}\text { FAD } 8 \mathrm{H}-\mathrm{CC} \text {; above } 8 \mathrm{H}-1,45-47 \mathrm{~cm} \text {, continuous } \\
\text { occurrence }\end{array}$ \\
\hline A. golownini & FAD $7 \mathrm{H} \mathrm{CC}$ & FAD $7 \mathrm{H}-7,45-47 \mathrm{~cm}$ \\
\hline C. spongothorax & FAD $7 \mathrm{H}-2,45-47 \mathrm{~cm}$ & $\begin{array}{l}\text { Part is unzoned interval FAD } 6 \mathrm{H}-6,45-47 \mathrm{~cm} \text {; } \\
\text { above } 6 \mathrm{H}-3,45-47 \mathrm{~cm} \text {, continuous occurrence }\end{array}$ \\
\hline
\end{tabular}

Note: Events are as identified by Lazarus (this volume) and Abelmann (this volume). The preservation of radiolarians is poor in this hole, and reworking and downhole contamination may be a problem. Therefore, the zonal boundaries need further discussion. 


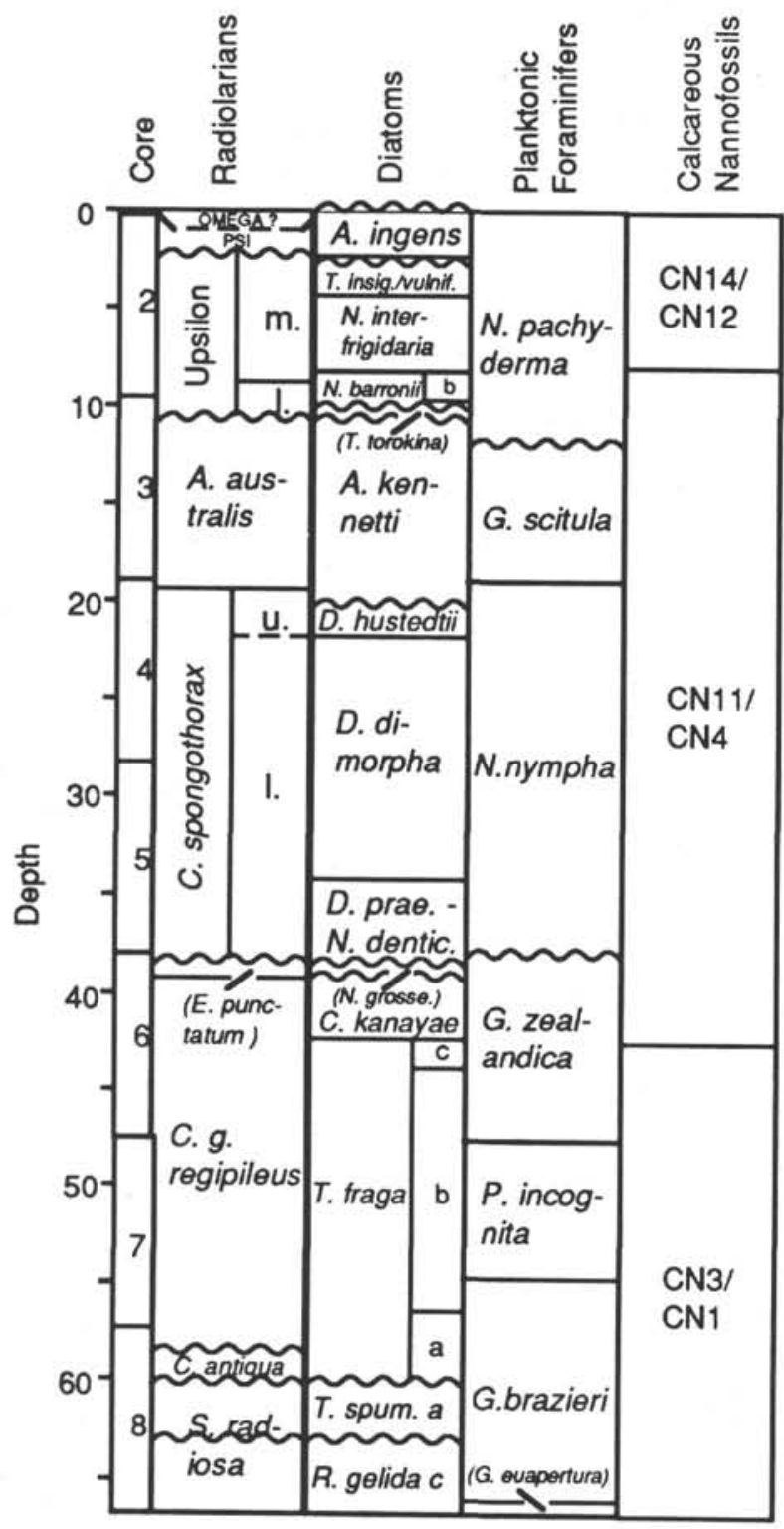

Figure 5. Summary figure showing stratigraphic position of biostratigraphic zones, Hole 748B. The slight differences in position of zonal boundaries between the microfossil groups are caused, in part, by different sample spacing.

correlating all ODP sections from Legs 113, 114, 119, and 120 through graphic correlation techniques to determine which sites are the most complete and best calibrated to serve as stratigraphic reference sections for this region; (5) producing composite biostratigraphic reference sections; and (6) linking these Southern Ocean records to the lower latitude regions and to the Antarctic shelf through calcareous and siliceous stratigraphy, respectively, through magnetic stratigraphy, and through strontium, oxygen, and carbon isotope stratigraphy.

The broad N-S transect of Legs 119 and 120 are ideally suited to the above tasks because of their broad latitudinal coverage. We also need to address the potentials for diachroneity and to place the periods of plankton and benthic foraminifer evolution/ extinction and migration, and the timing of the development of Antarctic endemic assemblages within the context of paleocli- mate change. These goals demand a major undertaking that will require the cooperation of many recent Southern Ocean ODP biostratigraphers, first applied to each fossil group and then to site-by-site correlations of all microfossil groups, magnetic stratigraphy, and chemostratigraphy. We have illustrated that stratigraphic ages can be resolved to within $\sim 200 \mathrm{k} . \mathrm{y}$. of uncertainty in many intervals, but the potential for greater resolution is higher when all data are compiled and applied, and lesser known plankton species are documented, tested, and employed in biostratigraphic correlations.

\section{ACKNOWLEDGMENTS}

We thank David K. Watkins for his attention to the production of this paper in the absence of its senior author during the final stages of production. John A. Barron, Jack G. Baldauf, and Rainer Gersonde provided preprints of their biostratigraphic papers from ODP Legs 119 and 113 and contributed helpful discussions. Preparation of this contribution was supported by USSAC and NSF (No. DPP-876411) grants to D. M. Harwood.

\section{REFERENCES}

Abelmann, A., 1990. Oligocene to middle Miocene radiolarian stratigraphy of southern high latitudes from Leg 113, Sites 689-690, Maud Rise. In Barker, P. F., Kennett, J. P., et al., Proc. ODP, Sci. Results, 113: College Station, TX (Ocean Drilling Program), 675-708.

Baldauf, J. G., and Barron, J. A., 1991. Diatom biostratigraphy: Kerguelen Plateau and Prydz Bay regions of the Southern Ocean. In Barron, J., Larsen, B., Baldauf, J. G., et al., Proc. ODP, Sci. Results, 119: College Station, TX (Ocean Drilling Program), 547-598.

Barker, P. F., Kennett, J. P., et al., 1988. Proc. ODP, Init. Repts., 113: College Station, TX (Ocean Drilling Program).

1990. Proc. ODP, Sci. Results, 113: College Station, TX (Ocean Drilling Program).

Barron, J. A., 1985. Late Eocene to Holocene diatom biostratigraphy of the equatorial Pacific Ocean, Deep Sea Drilling Project Leg 85. In Mayer, L., Theyer, F., Thomas, E., et al., Init. Repts. DSDP, 85: Washington (U.S. Govt. Printing Office), 413-456.

Barron, J. A., Nigrini, C. A., Pujos, A., Saito, T., Theyer, F., Thomas, E., and Weinreich, N., 1985. Synthesis of biostratigraphy, central equatorial Pacific, Deep Sea Drilling Project Leg 85: refinement of Oligocene to Quaternary biochronology. In Mayer, L., Theyer, F., Thomas, E., et al., Init. Repts. DSDP, 85: Washington (U.S. Govt. Printing Office), 905-934.

Barron, J., Larsen, B., et al., 1989. Proc. ODP, Init. Repts., 119: College Station, TX (Ocean Drilling Program).

Barron, J. A., Baldauf, J. G., Barrera, E., Caulet, J.-P., Huber, B. T. Keating, B. H., Lazarus, D., Sakai, H., Thierstein, H. R., and Wei, W., 1991. Biochronologic and magnetochronologic synthesis of Leg 119 sediments from the Kerguelen Plateau and Prydz Bay, Antarctica. In Barron, J., Larsen, B., et al., Proc. ODP, Sci. Results, 119: College Station, TX (Ocean Drilling Program), 813-848.

Berggren, W. A., Kent, D. V., Flynn, J. J., and Van Couvering, J. A., 1985a. Cenozoic geochronology. Geol. Soc. Am. Bull., 96:14071418.

Berggren, W. A., Kent, D. V., and Van Couvering, J. A., 1985b. The Neogene: Part 2. Neogene geochronology and chronostratigraphy. In Snelling, N. J. (Ed.), The Chronology of the Geological Record. Geol. Soc. London Mem., 10:211-260.

Gersonde, R., Abelmann, A., Burckle, L. H., Hamilton, N., Lazarus, D., McCartney, K., O'Brien, P., Spieß, V., and Wise, S. W., Jr., 1990. Biostratigraphic synthesis of Neogene siliceous microfossils from the Antarctic Ocean, ODP Leg 113 (Weddell Sea). In Barker, P. F., Kennett, J. P., et al., Proc. ODP, Sci. Results, 113: College Station, TX (Ocean Drilling Program), 915-936.

Jenkins, D. R., 1987. The geologic record of R/V Eltanin marine sediments from the Kerguelen Plateau and vicinity [M.S. thesis]. Univ. Florida, Gainesville. 
Okada, H., and Bukry, D., 1980. Supplementary modification and introduction of code numbers to the low-latitude coccolith biostratigraphic zonation (Bukry 1973; 1975). Mar. Micropaleontol., 5:321-325.

Schlich, R., Wise, S. W., Jr., et al., 1989. Proc. ODP, Init. Repts., 120: College Station, TX (Ocean Drilling Program).

Wei, W., and Thierstein, H. R., 1991. Upper Cretaceous and Cenozoic calcareous nannofossils of the Kerguelen Plateau (southern Indian Ocean) and Prydz Bay (East Antarctica). In Barron, J., Larsen, B., et al., Proc. ODP, Sci. Results, 119: College Station, TX (Ocean Drilling Program), 467-494.
Wei, W., and Wise, S. W., Jr., 1990. Middle Eocene to Pleistocene calcareous nannofossils recovered by Ocean Drilling Program Leg 113 in the Weddell Sea. In Barker, P. F., Kennett, J. P., et al., Proc. ODP, Sci. Results, 113: College Station, TX (Ocean Drilling Program), 639-666.

Date of initial receipt: 12 October 1990

Date of acceptance: 22 April 1991

Ms 120B-185 

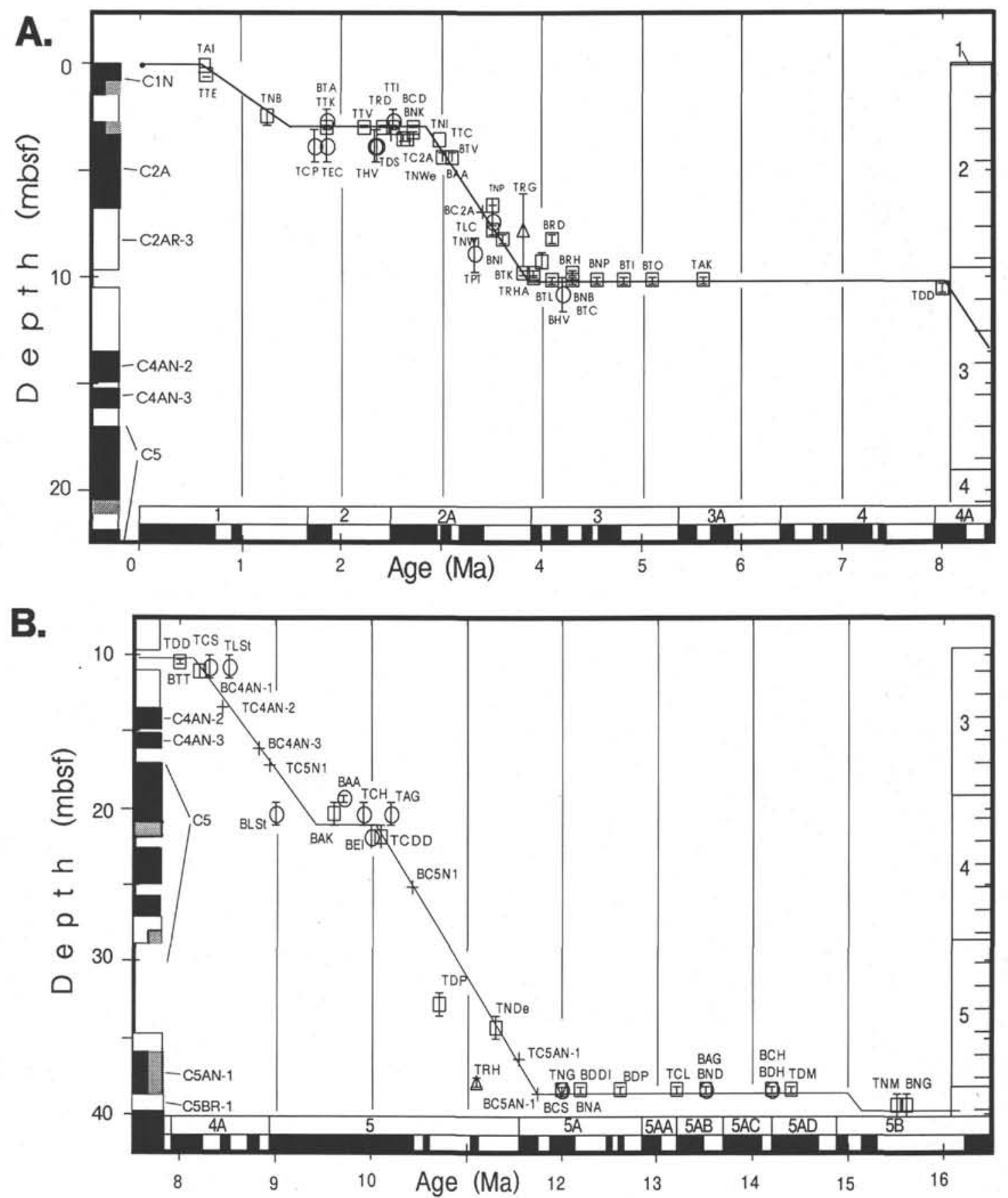

Figure 6. Age-depth plot showing biostratigraphic datums and magnetic stratigraphy for Hole 748B. Three-letter codes refer to microfossil datums listed in Table 1. The first letter refers to B for "base of range" and T for "top of range." The second letter is the first letter in the genus name, followed by one or two letters to identify the species. Open circles $=$ radiolarian datums, open squares $=$ diatom datums, triangle pointing $u p=$ foraminifer datums, triangle pointing down $=$ calcareous nannofossil datums, and plus sign $=$ magnetic polarity datums. Magnetic polarity zonation is presented at the left: black $=$ normal polarity, white $=$ reversed polarity, stippled $=$ mixed signal. Half-shaded intervals reflect initially uncertain polarity that was later determined by individual sample measurements. Standard geomagnetic polarity time scale of Berggren et al. (1985) is reproduced at the bottom of the figure with names of the anomaly correlatives. Error bars show depth of uncertainty in datum position caused by sample spacing. Cores are presented at the right side of the figure, with section marks indicated. A. 0-20 mbsf. B. $10-40 \mathrm{mbsf}$. C. $30-70$ mbsf. 
D. M. HARWOOD ET AL.

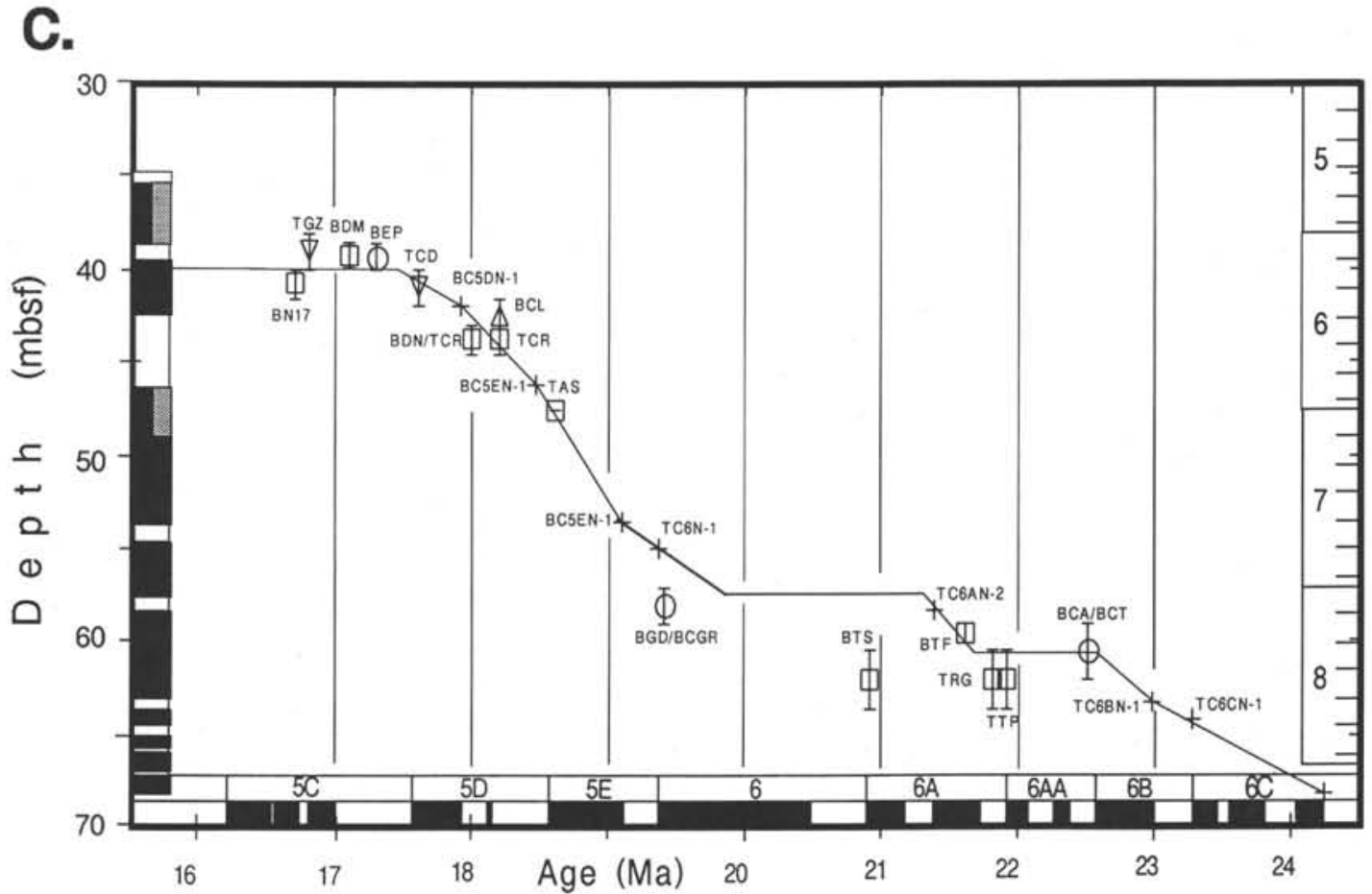

Figure 6 (continued). 
Table 5. Microprobe analysis of discrete, varicolored glauconite pellets, Hole $748 \mathrm{C}$.

\begin{tabular}{|c|c|c|c|c|}
\hline Datum & $\begin{array}{c}\text { Hole } 748 B \\
\text { age }(M a)\end{array}$ & $\begin{array}{l}\text { Published } \\
\text { age (Ma) }\end{array}$ & $\begin{array}{c}\text { Upper } \\
\text { interval } \\
\text { (m) }\end{array}$ & $\begin{array}{l}\text { Lower } \\
\text { interval } \\
\text { (m) }\end{array}$ \\
\hline \multicolumn{5}{|l|}{ Radiolarians: } \\
\hline TCP & - & 1.73 & 3.1 & 4.6 \\
\hline BTA & - & 1.85 & 2.05 & 3.1 \\
\hline TEC & - & 1.85 & 3.1 & 4.6 \\
\hline THV & - & 2.32 & 3.1 & 4.6 \\
\hline TDS & - & 2.34 & 3.1 & 4.6 \\
\hline BCD & - & 2.5 & 2.05 & 3.1 \\
\hline TPT & 3.7 & 3.32 & 8.05 & 9.6 \\
\hline TLC & * & 3.5 & 6.55 & 8.05 \\
\hline BHV & - & 4.2 & 10.05 & 11.55 \\
\hline TCS & * & 8.3 & 10.05 & 11.55 \\
\hline TLSt & 8.3 & 8.49 & 10.05 & 11.55 \\
\hline BLSt & 9.3 & 8.98 & 19.55 & 21.05 \\
\hline BAA & 9.3 & 9.7 & 19.1 & 19.55 \\
\hline TCH & - & 9.9 & 19.55 & 21.05 \\
\hline BEI & * & 10 & 21.05 & 22.55 \\
\hline TAG & 10 & 10.2 & 19.55 & 21.05 \\
\hline BCS & - & 12 & 38.1 & 38.56 \\
\hline BAG & - & 13.5 & 38.1 & 38.56 \\
\hline $\mathrm{BCH}$ & - & 14.2 & 38.1 & 38.56 \\
\hline BEP & - & 17.3 & 38.56 & 40.05 \\
\hline BGD/BCGR & $\gg>19.7$ & 19.4 & 57.1 & 59.06 \\
\hline BCA/BCT & - & 22.5 & 59.06 & 62.06 \\
\hline \multicolumn{5}{|l|}{ Diatoms: } \\
\hline TAI & * & 0.62 & 0.1 & 0.1 \\
\hline TTE & * & 0.65 & 0.43 & 0.57 \\
\hline TNB & * & 1.25 & 2.07 & 2.8 \\
\hline TTK & - & 1.88 & 2.8 & 3 \\
\hline TTV & - & 2.22 & 2.8 & 3 \\
\hline TTI & - & 2.5 & 2.8 & 3 \\
\hline TRD & - & 2.4 & 2.8 & 3 \\
\hline TNI & - & 2.6 & 2.8 & 3 \\
\hline BNK & 2.9 & 2.7 & 3.13 & 3.3 \\
\hline TTC & 2.9 & 3.1 & 3.3 & 3.57 \\
\hline TNWe & 2.9 & 2.64 & 3.3 & 3.57 \\
\hline BAA & 3 & 2.3 & 4.1 & 4.5 \\
\hline BTV & * & 3.1 & 4.1 & 4.5 \\
\hline TNP & 3.3 & 3.5 & 6.3 & 6.9 \\
\hline TNWI & * & 3.5 & 7.5 & 8 \\
\hline BNI & * & 3.6 & 8 & 8.4 \\
\hline BTK & 3.9 & 3.8 & 9.63 & 9.85 \\
\hline TRHA & 3.9 & 4 & 9.63 & 9.85 \\
\hline BTL & - & 3.9 & 9.94 & 10.03 \\
\hline BNWI & 3.8 & 4 & 8.8 & 9.6 \\
\hline BNB & - & 4.1 & 10.03 & 10.28 \\
\hline BRD & 3.6 & 4.1 & 8 & 8.4 \\
\hline BRH & 3.9 & 4.3 & 9.63 & 9.85 \\
\hline BNP & - & 4.55 & 10.03 & 10.28 \\
\hline BTC & - & 4.3 & 10.03 & 10.28 \\
\hline BTI & - & 4.8 & 10.03 & 10.28 \\
\hline BTO & - & 5.1 & 10.03 & 10.28 \\
\hline TAK & - & 5.6 & 10.03 & 10.28 \\
\hline TDD & - & 8 & 10.28 & 10.7 \\
\hline BTT & * & 8.2 & 10.7 & 11.57 \\
\hline
\end{tabular}

Table 5 (continued).

\begin{tabular}{|c|c|c|c|c|}
\hline Datum & $\begin{array}{c}\text { Hole 748B } \\
\text { age (Ma) }\end{array}$ & $\begin{array}{l}\text { Published } \\
\text { age (Ma) }\end{array}$ & $\begin{array}{c}\text { Upper } \\
\text { interval } \\
\text { (m) }\end{array}$ & $\begin{array}{l}\text { Lower } \\
\text { interval } \\
\text { (m) }\end{array}$ \\
\hline BAK & - & 9.6 & 19.57 & 21.07 \\
\hline TCDD & * & 10.1 & 21.07 & 22.57 \\
\hline TDP & 11.3 & 10.7 & 32.07 & 33.57 \\
\hline TNDe & $*$ & 11.3 & 33.57 & 35.07 \\
\hline BDDI & - & 12.2 & 38.1 & 38.57 \\
\hline BDP & - & 12.6 & 38.1 & 38.57 \\
\hline TNG & - & 12 & 38.1 & 38.57 \\
\hline TCL & - & 13.2 & 38.1 & 38.57 \\
\hline BND & - & 13.5 & 38.1 & 38.57 \\
\hline $\mathrm{BDH}$ & - & 14.2 & 38.1 & 38.57 \\
\hline TDM & - & 14.4 & 38.1 & 38.57 \\
\hline BNG & - & 15.5 & 38.57 & 40.07 \\
\hline TNM & - & 16.6 & 38.57 & 40.07 \\
\hline BDM & - & 17 & 38.57 & 40.07 \\
\hline BN17 & 17.8 & 16.7 & 40.07 & 41.57 \\
\hline BDN & 18.1 & 18 & 43.07 & 44.57 \\
\hline TCR & $*$ & 18.1 & 43.07 & 44.57 \\
\hline TAS & $*$ & 18.6 & 47.57 & 47.6 \\
\hline BTF & 21.7 & 20.8 & 59.07 & 60.07 \\
\hline TRG & - & 21.8 & 60.57 & 63.57 \\
\hline TTP & - & 21.9 & 60.57 & 63.57 \\
\hline BTS & $>>21.7$ & 20.9 & 60.57 & 63.57 \\
\hline \multicolumn{5}{|l|}{ Foraminifers: } \\
\hline BNA & - & 12 & 38.1 & 38.6 \\
\hline TGZ & - & 16.8 & 38.1 & 40 \\
\hline TCD & 17.6 & 16.8 & 40 & 42 \\
\hline \multicolumn{5}{|c|}{ Calcareous nannofossil: } \\
\hline TRG & $*$ & 3.8 & 6.08 & 9.5 \\
\hline TRH & 11.8 & 11.1 & 37.62 & 38.1 \\
\hline $\mathrm{BCL}$ & 18.1 & 18.2 & 41.68 & 43.18 \\
\hline \multicolumn{5}{|c|}{ Magnetic anomaly correlatives: } \\
\hline TC2A & & 2.47 & 3.25 & 3.25 \\
\hline $\mathrm{BC} 2 \mathrm{~A}$ & & 3.4 & 6.95 & 6.95 \\
\hline TC4AN-2 & & 8.41 & 14 & 14 \\
\hline TC4AN-3 & & 8.71 & 15.2 & 15.2 \\
\hline BC4AN-3 & & 8.8 & 16 & 16 \\
\hline TC5N-1 & & 8.92 & 17.25 & 17.25 \\
\hline BCSN-1 & & 10.42 & 25.1 & 25.1 \\
\hline TC5AN-1 & & 11.55 & 35.2 & 35.2 \\
\hline BC5AN-1 & & 11.73 & 38 & 38 \\
\hline BC5DN-1 & & 17.9 & 42 & 42 \\
\hline TC5EN-1 & & 18.56 & 46.5 & 46.5 \\
\hline BC5EN-1 & & 19.09 & 53.6 & 53.6 \\
\hline TC6N-1 & & 19.35 & 55 & 55 \\
\hline TC6AN-1 & & 20.88 & 59.1 & 59.1 \\
\hline BC6BN-1 & & 22.97 & 62.5 & 62.5 \\
\hline TC6CN-1 & & 23.27 & 64.5 & 64.5 \\
\hline BC6CN-3 & & 24.21 & 68 & 68 \\
\hline
\end{tabular}

Notes: Biostratigraphic datums, three-letter codes, and published ages are as in Table 1. Asterisks $\left({ }^{*}\right)$ indicate general agreement with published ages, whereas numerical ages suggest ages different from published values at that site. Dashes $(-)$ indicate intervals of no data for comparison, usually caused by a hiatus level. 
Table 6. Identification of magnetic anomaly correlatives in Hole 748B, following the age-depth plot in Figure 6.

\begin{tabular}{|c|c|c|}
\hline $\begin{array}{l}\text { Magnetic } \\
\text { event }\end{array}$ & $\begin{array}{l}\text { This } \\
\text { paper }\end{array}$ & $\begin{array}{l}\text { Inokuchi et } \\
\text { al. (this } \\
\text { volume) }\end{array}$ \\
\hline $\mathrm{C} 1$ & $\mathrm{C} 1$ & $\mathrm{x}$ \\
\hline $\mathrm{C} 2$ & $\mathrm{x}$ & $\mathrm{x}$ \\
\hline C2AN-1 & $\mathrm{C} 2 \mathrm{~A}$ & $\mathrm{C} 2 \mathrm{~A}$ \\
\hline C2AN-2 & $\mathrm{C} 2 \mathrm{~A}$ & $\mathrm{C} 2 \mathrm{~A}$ \\
\hline C2AN-3 & $\mathrm{C} 2 \mathrm{~A}$ & $\mathrm{C} 2 \mathrm{~A}$ \\
\hline $\mathrm{C} 3 \mathrm{~N}-1$ & $\mathrm{X}$ & $\mathrm{x}$ \\
\hline $\mathrm{C} 3 \mathrm{~N}-2$ & $\mathrm{X}$ & $\mathrm{X}$ \\
\hline $\mathrm{C} 3 \mathrm{~N}-3$ & $\mathrm{X}$ & $\mathrm{X}$ \\
\hline C3AN-1 & $\mathrm{x}$ & \# \\
\hline $\mathrm{C} 3 \mathrm{AN}-2$ & $\mathrm{x}$ & \# \\
\hline $\mathrm{C} 4 \mathrm{~N}-1$ & $\mathrm{x}$ & \# \\
\hline $\mathrm{C} 4 \mathrm{~N}-2$ & $\mathrm{x}$ & \# \\
\hline $\mathrm{C} 4 \mathrm{~N}-3$ & $\mathrm{X}$ & \# \\
\hline C4AN-1 & $\mathrm{x}$ & \# \\
\hline C4AN-2 & C4AN-2 & C3AN-1 \\
\hline C4AN-3 & C4AN-3 & $\mathrm{CC} 3 \mathrm{AN}-2$ \\
\hline $\mathrm{C} 5 \mathrm{~N}-1$ & C5 & $\mathrm{x}$ \\
\hline $\mathrm{C} 5 \mathrm{~N}-2$ & C5 & $\mathrm{C} 4$ \\
\hline $\mathrm{C} 5 \mathrm{~N}-3$ & C5 & $\mathrm{C} 4 \mathrm{~A}$ \\
\hline C5AN-1 & C5AN-1 & C5C \\
\hline C5AN-2 & $\mathrm{x}$ & $\mathrm{x}$ \\
\hline C5AN-3 & $\mathrm{x}$ & $\mathrm{x}$ \\
\hline C5AN-4 & $\mathrm{x}$ & $\mathrm{x}$ \\
\hline C5AA & $\mathrm{x}$ & $\mathrm{x}$ \\
\hline $\mathrm{C} 5 \mathrm{AB}$ & $\mathrm{X}$ & $\mathrm{x}$ \\
\hline C5AC & $\mathrm{X}$ & $\mathrm{X}$ \\
\hline C5AD & $\mathrm{X}$ & $\mathrm{X}$ \\
\hline C $5 \mathrm{BN}-1$ & $\mathrm{x}$ & $\mathrm{X}$ \\
\hline C $5 \mathrm{BN}-2$ & $\mathrm{x}$ & $\mathrm{x}$ \\
\hline $\mathrm{C} 5 \mathrm{CN}-1$ & $\mathrm{x}$ & $\#$ \\
\hline $\mathrm{C} 5 \mathrm{CN}-2$ & $\mathrm{x}$ & $\#$ \\
\hline $\mathrm{C} 5 \mathrm{CN}-3$ & $\mathrm{x}$ & \# \\
\hline C5DN-1 & C5DN-1 & C5D \\
\hline C $5 \mathrm{DN}-2$ & $\mathrm{x}$ & $\mathrm{X}$ \\
\hline C5E & C5E & C6 \& C5E \\
\hline C6 & C6 & C6A \\
\hline C6AN-1 & C6AN-1 & C6AA \\
\hline C6AN-2 & $\mathrm{x}$ & $\mathrm{X}$ \\
\hline C6AAN-1 & $\mathrm{X}$ & $\#$ \\
\hline C6AAN-2 & $\mathrm{x}$ & \# \\
\hline C6B & C6B & C6AA \\
\hline $\mathrm{C} 6 \mathrm{CN}-1$ & $\mathrm{C} 6 \mathrm{CN}-1$ & $\mathrm{C} 6 \mathrm{CN}-1$ \\
\hline $\mathrm{C} 6 \mathrm{CN}-2$ & $\mathrm{C} 6 \mathrm{CN}-2$ & $\mathrm{C} 6 \mathrm{CN}-3$ \\
\hline $\mathrm{C} 6 \mathrm{CN}-3$ & $\mathrm{C} 6 \mathrm{CN}-3$ & $\mathrm{C} 6 \mathrm{CN}-3$ \\
\hline
\end{tabular}

Notes: Differences in interpretation between this paper and that of Inokuchi and Heider (this volume) are identified. Magnetic polarity events not identified in this hole, usually caused by the presence of a hiatus, are identified by the letter $\mathrm{X} . \#=$ identified at a different level.

Table 7. Comparison of Miocene radiolarian events in Hole 748B.

\begin{tabular}{|c|c|c|}
\hline Hole 748B & Lazarus (this volume) & Abelmann (this volume) \\
\hline $\begin{array}{l}\text { C. tehapera } \\
\text { C. antiqua }\end{array}$ & $\begin{array}{l}8 \mathrm{H}-2,45-47 \mathrm{~cm} \text {, the } \\
\text { oldest sample } \\
\text { investigated }\end{array}$ & $\begin{array}{l}\text { FAD } 8 \mathrm{H}-2,45-47 \mathrm{~cm} ; \\
S \text {. radiosa Zone below this } \\
\text { sample }\end{array}$ \\
\hline C. longithorax & \multicolumn{2}{|c|}{ This zone is lacking because of a hiatus. } \\
\hline C. golli regipileus & $\begin{array}{l}\text { No definition of } \\
\text { species }\end{array}$ & FAD $8 \mathrm{H}-1,45-47 \mathrm{~cm}$ \\
\hline E. punctatum & $\begin{array}{l}\text { FAD } 6 \mathrm{H}-1,65-67 \mathrm{~cm} \text {; } \\
\text { only in } 2 \text { samples } \\
\text { below this }\end{array}$ & FAD $6 \mathrm{H}-1,65-67 \mathrm{~cm}$ \\
\hline C. spongothorax & $\begin{array}{l}\mathrm{FAD}(?) 5 \mathrm{H}-6 \text {, } \\
45-47 \mathrm{~cm} \text {, and } \\
6 \mathrm{H}-1,65-67 \mathrm{~cm}\end{array}$ & $\begin{array}{r}\text { FAD between } 5 \mathrm{H}-5,72-76 \\
\mathrm{~cm} \text {, and } 6 \mathrm{H}-1,65-67 \mathrm{~cm}\end{array}$ \\
\hline
\end{tabular}

Note: Events are as identified by Lazarus (this volume) and Abelmann (this volume).

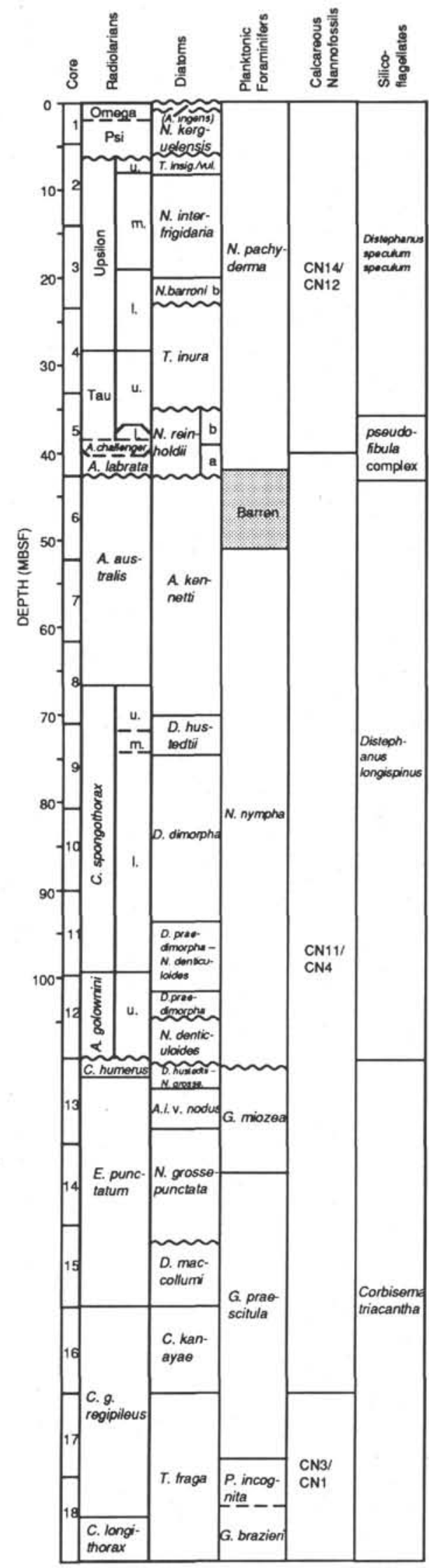

Figure 7. Summary figure showing stratigraphic position of biostratigraphic zones, Hole 751A. The slight differences in position of zonal boundaries between the microfossil groups are caused, in part, by different sample spacing. 

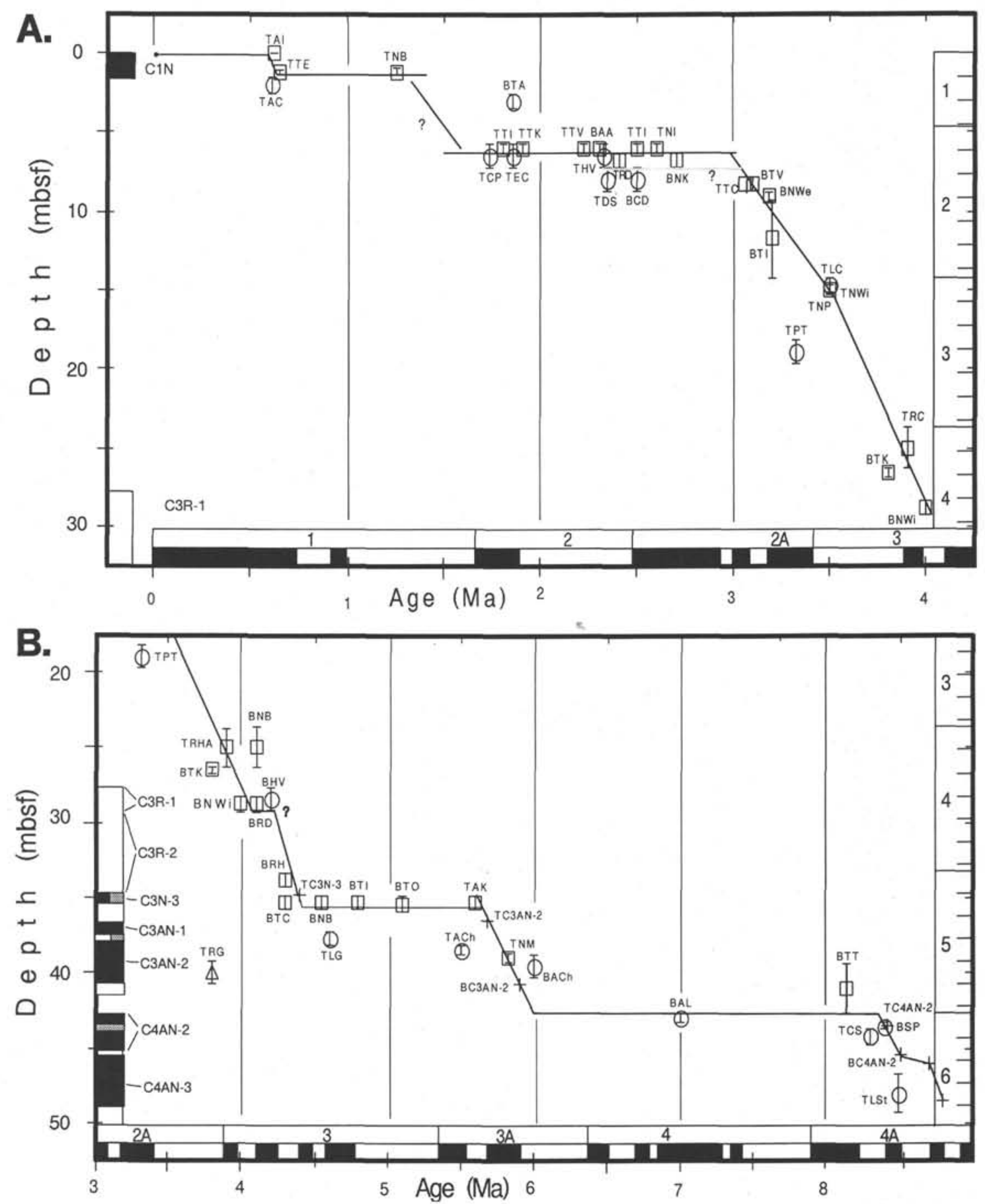

Figure 8. Age-depth plot showing biostratigraphic datums and magnetic stratigraphy, Hole 751A. Three-letter codes refer to microfossil datums listed in Table 1. The first letter refers to B for "base of range" and T for "top of range." The second letter is the first letter in the genus name, followed by one or two letters to identify the species. Open circles = radiolarian datums, open squares $=$ diatom datums, triangle pointing up $=$ foraminifer datums, triangle pointing down $=$ calcareous nannofossil datums, and plus sign $=$ magnetic polarity datums. Magnetic polarity zonation is presented at the left: black $=$ normal polarity, white $=$ reversed polarity, stippled $=$ mixed signal. Half-shaded intervals reflect initially uncertain polarity that was later determined by individual sample measurements. Standard geomagnetic polarity time scale of Berggren et al. (1985) is reproduced at the bottom of the figure with names of the anomaly correlatives. Error bars show depth of uncertainty in datum position due to sample spacing. Cores are presented at the right side of the figure with section marks indicated. A. 0-30 mbsf. B. 20-50 mbsf. C. 40-120 mbsf. D. 100-150 mbsf. E. $130-170$ mbsf. 

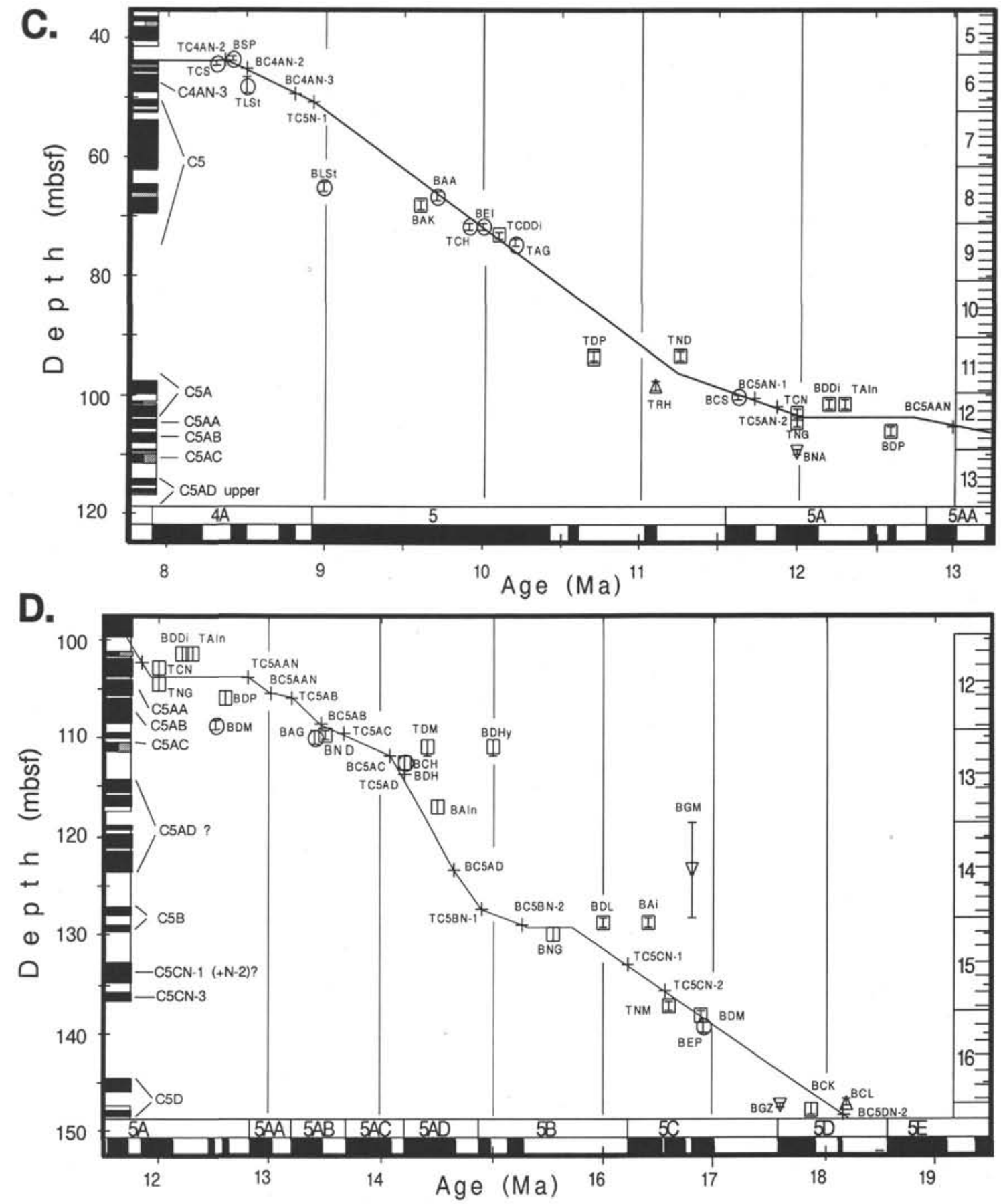

Figure 8 (continued). 
E.

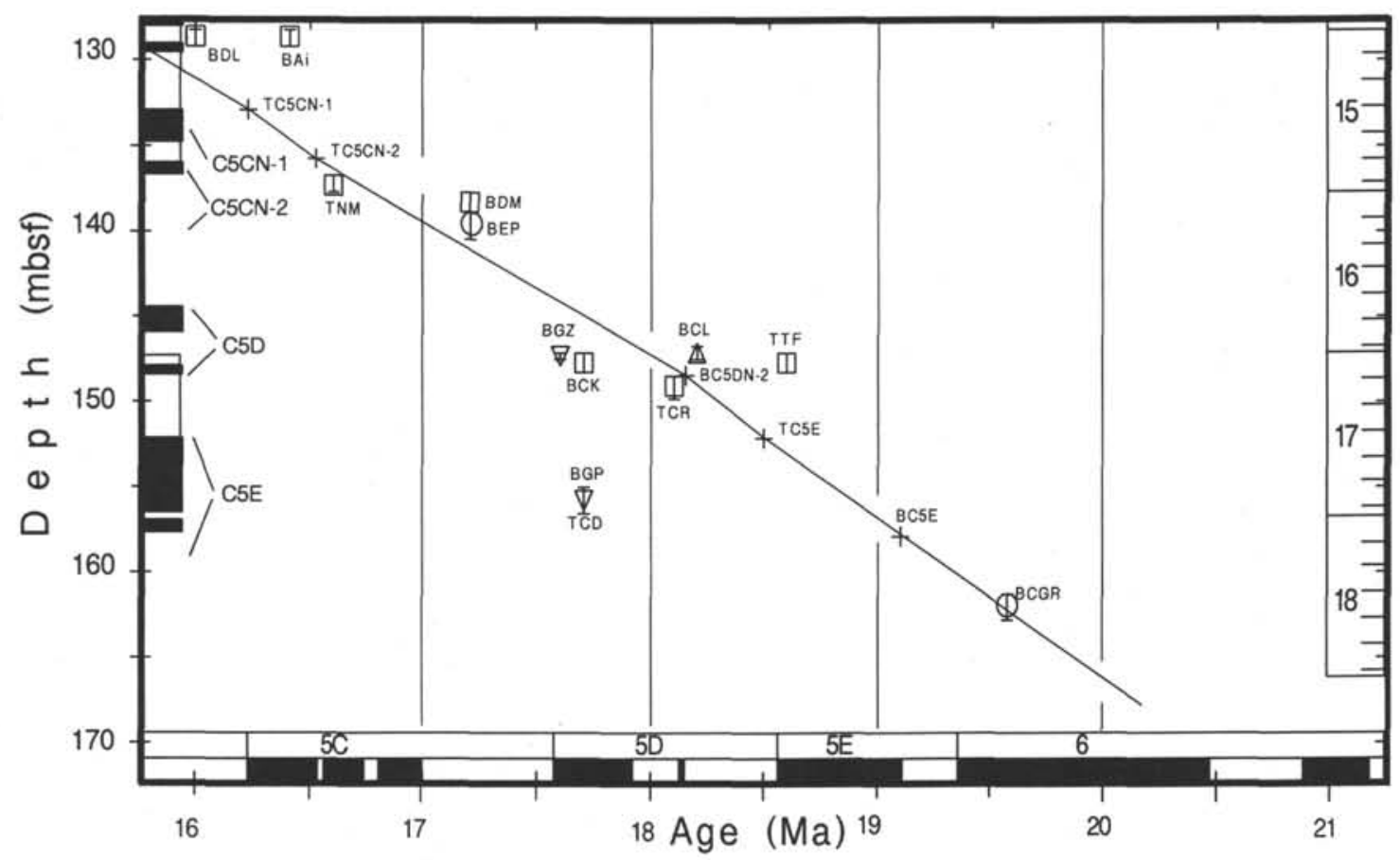

Figure 8 (continued). 
Table 8. Biostratigraphic events used to construct agedepth plots for Hole 751A.

\begin{tabular}{|c|c|c|c|c|}
\hline Datum & $\begin{array}{c}\text { Hole } 751 \mathrm{~A} \\
\text { age }(\mathrm{Ma})\end{array}$ & $\begin{array}{l}\text { Published } \\
\text { age (Ma) }\end{array}$ & $\begin{array}{c}\text { Upper } \\
\text { interval } \\
\text { (m) }\end{array}$ & $\begin{array}{l}\text { Lower } \\
\text { interval } \\
\text { (m) }\end{array}$ \\
\hline \multicolumn{5}{|c|}{ Radiolarians: } \\
\hline TAC & ${ }^{*}$ & 0.61 & 1.5 & 2.56 \\
\hline TCP & - & 1.73 & 5.68 & 7.18 \\
\hline BTA & * & 1.85 & 2.56 & 3.45 \\
\hline TEC & - & 1.85 & 5.68 & 7.18 \\
\hline THV & - & 2.32 & 5.68 & 7.18 \\
\hline TDS & - & 2.34 & 7.18 & 8.68 \\
\hline BCD & - & 2.5 & $\begin{array}{r}7.18 \\
10.0\end{array}$ & 8.68 \\
\hline TPT & 3.65 & 3.32 & 18.18 & 19.68 \\
\hline TLC & * & 3.5 & 14.2 & 15.18 \\
\hline BHV & $*$ & 4.2 & 27.68 & 29.18 \\
\hline TLG & 5.75 & 4.6 & 37.18 & 38.18 \\
\hline TACh & 5.75 & 5.5 & 38.18 & 38.68 \\
\hline BACh & 5.9 & 6 & 38.68 & 40.18 \\
\hline BAL & - & 7 & 42.7 & 43.23 \\
\hline TCS & 8.45 & 8.3 & 43.68 & 44.7 \\
\hline BSP & * & 8.4 & 43.23 & 43.68 \\
\hline TLSt & 8.6 & 8.49 & 46.68 & 49.2 \\
\hline BLSt & 9.6 & 8.98 & 64.16 & 65.68 \\
\hline BAA & * & 9.7 & 65.68 & 67.18 \\
\hline $\mathrm{TCH}$ & * & 9.9 & 71.2 & 72.18 \\
\hline BEI & * & 10 & 71.2 & 72.18 \\
\hline TAG & * & 10.2 & 73.68 & 75.18 \\
\hline BCS & * & 11.6 & 99.7 & 101 \\
\hline BDM & 13.3 & 12.5 & 109.2 & 109.5 \\
\hline BAG & 13.6 & 13.4 & 109.2 & 110.7 \\
\hline $\mathrm{BCH}$ & * & 14.2 & 112.5 & 113.2 \\
\hline BEP & 17 & 17.3 & 137.7 & 138.7 \\
\hline BCCGR & * & 19.4 & 150.2 & 152.2 \\
\hline \multicolumn{5}{|l|}{ Diatoms: } \\
\hline TAI & * & 0.62 & 0 & 0.1 \\
\hline TTP & * & 0.65 & 1.05 & 1.45 \\
\hline TNB & - & 1.25 & 1 & 1.45 \\
\hline TRD & - & 2.4 & 6.3 & 7.25 \\
\hline TTI & - & 1.8 & 5.75 & 6.3 \\
\hline TTK & - & 1.8 & 5.75 & 6.3 \\
\hline TTV & - & 2.22 & 5.75 & 6.3 \\
\hline BAA & - & 2.3 & 5.75 & 6.3 \\
\hline TTI & - & 2.5 & 5.75 & 6.3 \\
\hline BNK & - & 2.7 & 6.3 & 7.25 \\
\hline TNI & - & 2.6 & 5.75 & 6.3 \\
\hline TTC & * & 3.1 & 7.8 & 8.75 \\
\hline BTV & * & 3.1 & 7.8 & 8.75 \\
\hline BNWe & * & 3.2 & 8.75 & 9.3 \\
\hline BTI & * & 3.2 & 9.3 & 14.2 \\
\hline TNP & * & 3.5 & 14.67 & 15.25 \\
\hline TNWi & * & 3.5 & 14.67 & 15.25 \\
\hline BTK & 3.9 & 3.8 & 26.25 & 26.8 \\
\hline BRD & 4 & 4.1 & 28.3 & 29.25 \\
\hline TRHA & * & 3.9 & 23.71 & 26.25 \\
\hline BNWi & * & 4 & 28.3 & 29.25 \\
\hline BNB & 3.9 & 4.1 & 23.7 & 26.25 \\
\hline BTC & 4.4 & 4.3 & 34.8 & 35.75 \\
\hline BRH & 4.4 & 4.3 & 33.3 & 34.25 \\
\hline BNB & - & 4.55 & 34.8 & 35.75 \\
\hline BTI & - & 4.8 & 34.8 & 35.75 \\
\hline BTO & - & 5.1 & 34.8 & 35.95 \\
\hline TNM & $*$ & 5.8 & 38.75 & 39.3 \\
\hline TAK & - & 5.6 & 34.8 & 35.75 \\
\hline BTT & - & 8.2 & 39.3 & 42.7 \\
\hline BAK & 9.7 & 9.6 & 67.25 & 68.75 \\
\hline
\end{tabular}

Table 8 (continued).

\begin{tabular}{|c|c|c|c|c|}
\hline Datum & $\begin{array}{c}\text { Hole } 751 \mathrm{~A} \\
\text { age }(\mathrm{Ma})\end{array}$ & $\begin{array}{l}\text { Published } \\
\text { age (Ma) }\end{array}$ & $\begin{array}{c}\text { Upper } \\
\text { interval } \\
\text { (m) }\end{array}$ & $\begin{array}{l}\text { Lower } \\
\text { interval } \\
\text { (m) }\end{array}$ \\
\hline TCDDi & * & 10.1 & 72.75 & 73.75 \\
\hline TDP & 11.1 & 10.7 & 92.75 & 94.75 \\
\hline TND & 11.1 & 11.3 & 92.75 & 94.25 \\
\hline BDDi & 11.9 & 12.2 & 100.75 & 102.25 \\
\hline BDP & 12.8 & 12.6 & 105.25 & 106.75 \\
\hline TNG & $*$ & 12 & 103.75 & 105.25 \\
\hline TAIn & 11.9 & 12.3 & 100.75 & 102.25 \\
\hline BDHy & 14 & 15 & 110.25 & 111.75 \\
\hline BAIn & 14.3 & 14.5 & 116.25 & 117.75 \\
\hline BND & 13.6 & 13.5 & 109.2 & 110.25 \\
\hline BDH & 14.1 & 14.2 & 111.75 & 113.25 \\
\hline TDM & 14 & 14.4 & 110.25 & 111.75 \\
\hline BNG & 15.3 & 15.5 & 129.25 & 130.75 \\
\hline $\mathrm{BAi}$ & 15.7 & 16.4 & 128.2 & 129.25 \\
\hline TNM & $*$ & 16.6 & 136.75 & 137.7 \\
\hline BDL & 15.7 & 16 & 128.2 & 129.25 \\
\hline BDM & 16.9 & 17 & 137.7 & 138.75 \\
\hline BCK & 18.1 & 17.8 & 147.2 & 148.25 \\
\hline TTF & 18.1 & 18.6 & 147.2 & 148.25 \\
\hline TCR & 18.2 & 18.1 & 148.45 & 149.75 \\
\hline \multicolumn{5}{|c|}{ Foraminifers: } \\
\hline BNA & 13.3 & 12 & 109.2 & 110 \\
\hline BGM & - & 16.8 & 118.7 & 128.2 \\
\hline TCD & 18.8 & 16.8 & 118.7 & 128.2 \\
\hline BGZ & 18 & 17.6 & 147.2 & 147.5 \\
\hline BGP & 18.8 & 17.7 & 155 & 156.5 \\
\hline \multicolumn{5}{|c|}{ Calcareous nannofossils: } \\
\hline TRG & 5.8 & 3.8 & 39.25 & 40.75 \\
\hline TRH & 11.3 & 11.1 & 97.75 & 99.25 \\
\hline $\mathrm{BCL}$ & 18.1 & 18.2 & 146.72 & 147.42 \\
\hline \multicolumn{5}{|c|}{ Magnetic anomaly correlatives: } \\
\hline TC3AN-2 & & 5.7 & 36.5 & 36.5 \\
\hline BC3AN-2 & & 5.89 & 41 & 41 \\
\hline TC4AN-2 & & 8.4 & 43.6 & 43.6 \\
\hline BC4AN-2 & & 8.55 & 44.9 & 44.9 \\
\hline TC4AN-3 & & 8.7 & 45.2 & 45.2 \\
\hline BC4AN-3 & & 8.8 & 49 & 49 \\
\hline TC5N-1 & & 8.92 & 50.75 & 50.75 \\
\hline BC5AN-1 & & 11.73 & 99.7 & 99.7 \\
\hline TC5AN-2 & & 11.86 & 102 & 102 \\
\hline TC5AAN & & 12.83 & 104 & 104 \\
\hline BC5AAN & & 13.01 & 105.5 & 105.5 \\
\hline TC5AB & & 13.2 & 106 & 106 \\
\hline BC5AB & & 13.46 & 108 & 108 \\
\hline TC5AC & & 13.69 & 109.5 & 109.5 \\
\hline BC5AC & & 14.08 & 111.8 & 111.8 \\
\hline TC5AD & & 14.2 & 113.8 & 113.8 \\
\hline BC5AD & & 14.66 & 123.3 & 123.3 \\
\hline TC5BN-1 & & 14.87 & 127.2 & 127.2 \\
\hline BC5BN-2 & & 15.27 & 129.2 & 129.2 \\
\hline TC5CN-1 & & 16.22 & 132.9 & 132.9 \\
\hline TC5CN-2 & & 16.58 & 136.2 & 136.2 \\
\hline BC5DN-2 & & 18.15 & 148.5 & 148.5 \\
\hline TC5E & & 18.5 & 152.1 & 152.1 \\
\hline BC5E & & 19.09 & 157.9 & 157.9 \\
\hline
\end{tabular}

Notes: Biostratigraphic datums, three-letter codes, and published ages are as in Table 1. Asterisks $\left(^{*}\right)$ indicate general agreement with published ages, whereas numerical ages suggest ages different from published values at that site. Dashes (-) indicate intervals of no data for comparison, usually caused by a hiatus level. 
Table 9. Identification of magnetic anomaly correlatives in Hole 751A following the age-depth plot in Figure 9.

\begin{tabular}{|c|c|c|}
\hline $\begin{array}{l}\text { Magnetic } \\
\text { event }\end{array}$ & $\begin{array}{l}\text { This } \\
\text { paper }\end{array}$ & $\begin{array}{l}\text { Heider et } \\
\text { al. (this } \\
\text { volume) }\end{array}$ \\
\hline $\mathrm{C} 1$ & $\mathrm{C} 1$ & $\mathrm{X}$ \\
\hline $\mathrm{C} 2$ & $\mathrm{X}$ & $\mathrm{X}$ \\
\hline C2AN-1 & $\mathrm{X}$ & $\mathrm{X}$ \\
\hline $\mathrm{C} 2 \mathrm{AN}-2$ & $\mathrm{X}$ & $\mathrm{X}$ \\
\hline C2AN-3 & $\mathrm{X}$ & $\mathrm{x}$ \\
\hline $\mathrm{C} 3 \mathrm{~N}-1$ & $\mathrm{X}$ & $\mathrm{X}$ \\
\hline C $3 \mathrm{~N}-2$ & $\mathrm{X}$ & $\mathrm{X}$ \\
\hline $\mathrm{C} 3 \mathrm{~N}-3$ & C 3 N-3? & $\mathrm{x}$ \\
\hline C3AN-I & $\mathrm{X}$ & $\mathrm{C} 3 \mathrm{~A}$ \\
\hline C3AN-2 & C $3 \mathrm{AN}-2$ & $\mathrm{C} 3 \mathrm{~A}$ \\
\hline $\mathrm{C} 4 \mathrm{~N}-1$ & $\mathrm{X}$ & $\mathrm{X}$ \\
\hline $\mathrm{C} 4 \mathrm{~N}-2$ & $\mathrm{X}$ & $\mathrm{X}$ \\
\hline $\mathrm{C} 4 \mathrm{~N}-3$ & $\mathrm{X}$ & $\mathrm{X}$ \\
\hline C4AN-1 & $\mathrm{x}$ & $\mathrm{C} 4 \mathrm{~A}$ \\
\hline C $4 A N-2$ & C4AN-2 & $\mathrm{C} 4 \mathrm{~A}$ \\
\hline C4AN-3 & C4AN-3 & $\mathrm{C} 4 \mathrm{~A}$ \\
\hline $\mathrm{C} 5 \mathrm{~N}-1$ & C5 & $\mathrm{C} 5$ \\
\hline $\mathrm{C} 5 \mathrm{~N}-2$ & C5 & C5 \\
\hline $\mathrm{C} 5 \mathrm{~N}-3$ & C5 & C5 \\
\hline C5AN-1 & C5AN-1 & C5A \\
\hline C5AN-2 & C5AN-2 & C5AA? \\
\hline C5AN-3 & $\mathrm{X}$ & $\mathrm{X}$ \\
\hline C5AN-4 & $\mathrm{x}$ & $\mathrm{X}$ \\
\hline CSAA & C5AA & $\#$ \\
\hline C5AB & C $5 \mathrm{AB}$ & C5AB? \\
\hline C5AC & C5AC & C5B \\
\hline CSAD & C5AD & $\mathrm{C} 5 \mathrm{C}$ \\
\hline C5BN-1 & C5BN-1 & $\#$ \\
\hline $\mathrm{C} 5 \mathrm{BN}-2$ & C5BN-2 & $\#$ \\
\hline $\mathrm{C} 5 \mathrm{CN}-1$ & $\mathrm{C} 5 \mathrm{CN}-1$ & C5D \\
\hline $\mathrm{C} 5 \mathrm{CN}-2$ & $\mathrm{C} 5 \mathrm{CN}-2$ & C5D \\
\hline C $5 \mathrm{CN}-3$ & $\mathrm{X}$ & $\#$ \\
\hline C5DN-1 & $?$ & \# \\
\hline C5DN-2 & $\mathrm{C} 5 \mathrm{DN}-2$ & $\#$ \\
\hline C5E & CSE & C5E \\
\hline
\end{tabular}

Notes: Differences in interpretation between this paper and that of Heider et al. (this volume) are identified. Magnetic polarity events not identified in this hole, usually caused by the presence of a hiatus, are identified by the letter X. The "\#" symbol indicates that the magnetic event was identified at a different depth in earlier interpretations.
Table 10. Comparison of Miocene radiolarian events in Hole 751A.

\begin{tabular}{|c|c|c|}
\hline Hole 751A & Lazarus (this volume) & $\begin{array}{c}\text { Abelmann } \\
\text { (this volume) }\end{array}$ \\
\hline C. longithorax & FAD $18 \mathrm{H}-\mathrm{CC}$ & (oldest sample) \\
\hline C. golli regipileus & $\begin{array}{l}\text { No definition of marker } \\
\text { species }\end{array}$ & FAD $18 \mathrm{H}-2,45-47 \mathrm{~cm}$ \\
\hline E. punctatum & $\begin{array}{l}\text { FAD between } 15 \mathrm{H}-\mathrm{CC} \text { and } \\
16 \mathrm{H}-\mathrm{CC}\end{array}$ & $\begin{array}{l}\text { FAD between } 15 \mathrm{H}-\mathrm{CC} \\
\text { and } 16 \mathrm{H}-1,98-100 \mathrm{~cm}\end{array}$ \\
\hline C. humerus & $\begin{array}{l}\text { FAD between } 12 \mathrm{H}-\mathrm{CC} \text { and } \\
13 \mathrm{H}-\mathrm{CC}\end{array}$ & $\begin{array}{l}\text { FAD between } 13 \mathrm{H}-3 \text {, } \\
32-36 \mathrm{~cm} \text {, and } \\
13 \mathrm{H}-3,98-100 \mathrm{~cm}\end{array}$ \\
\hline D. megalocephalis & $\begin{array}{l}\text { FAD(?) } 15 \mathrm{H}-\mathrm{CC} \text { (taxonomic } \\
\text { uncertainty) }\end{array}$ & $\begin{array}{l}\text { FAD } 11 \mathrm{H}-\mathrm{CC} \text { and } \\
12 \mathrm{H}-1,98-100 \mathrm{~cm}\end{array}$ \\
\hline C. spongothorax & $\begin{array}{l}\text { FAD } 11 \mathrm{H}-\mathrm{CC} \text { and } 12 \mathrm{H}-1 \text {, } \\
98-100 \mathrm{~cm}\end{array}$ & $\begin{array}{l}\text { FAD } 11 \mathrm{H}-\mathrm{CC} \text { and } \\
12 \mathrm{H}-1,98-100 \mathrm{~cm}\end{array}$ \\
\hline
\end{tabular}

Note: Events are as identified by Lazarus (this volume) and Abelmann (this volume). 


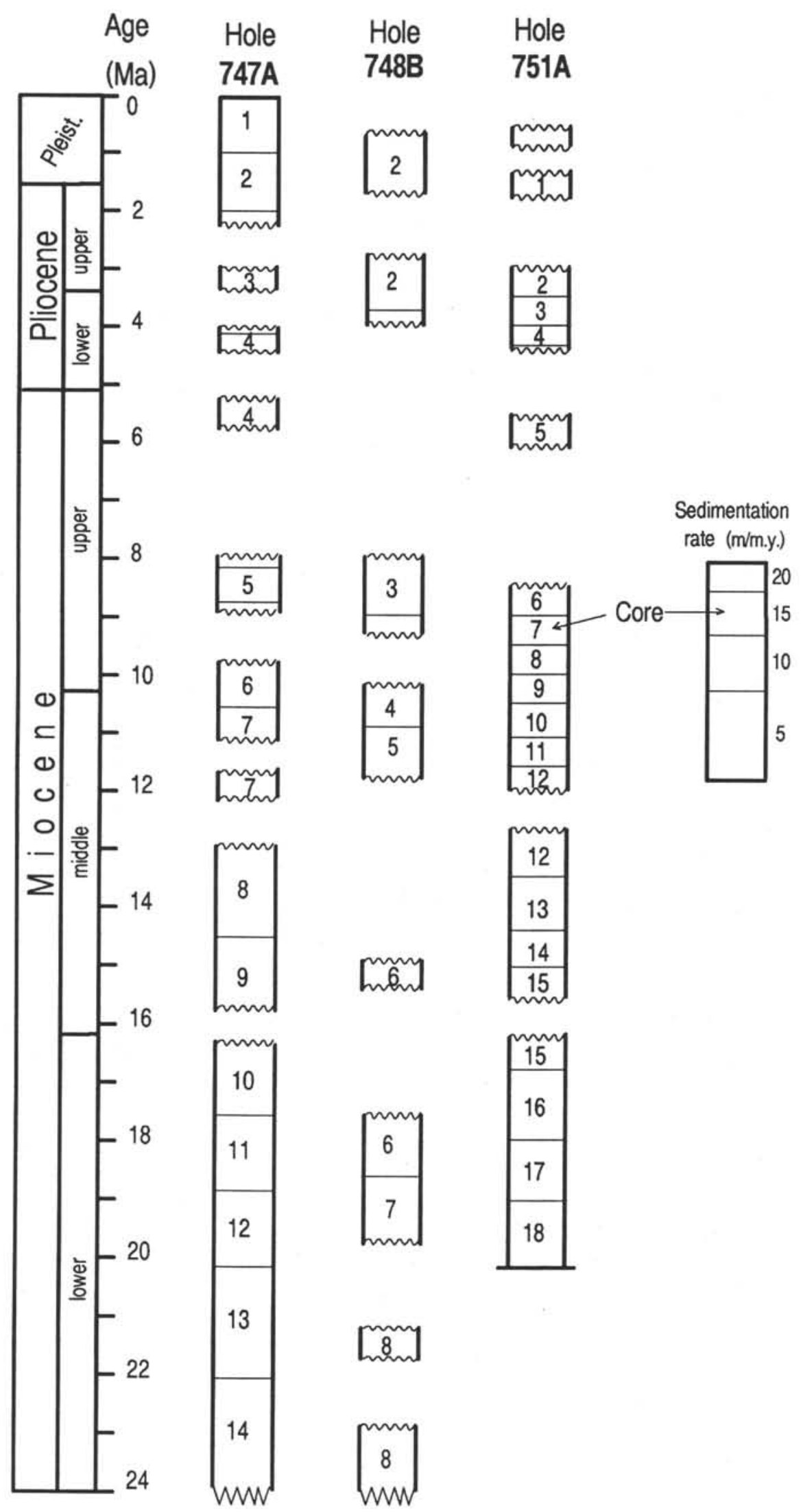

Figure 9. Age distribution of Neogene sediments recovered from Holes 747A, 748B, and $751 \mathrm{~A}$, showing the ages represented by hiatuses. Numbers within the columns reflect the core number. Approximate sediment accumulation rates can be determined by comparison with the scale at right. 